\title{
Observations and Dynamical Implications of Active Normal Faulting in South Peru
}

\author{
Sam Wimpenny ${ }^{1 *}$, Carlos Benavente ${ }^{2}$, Alex Copley ${ }^{1}$, Briant Garcia ${ }^{2}$, \\ Lorena Rossell ${ }^{2}$, Aisling O'Kane ${ }^{1}$, Enoch Aguirre ${ }^{2}$ \\ ${ }^{1}$ COMET, Bullard Laboratories, Department of Earth Sciences, University of Cambridge, UK \\ ${ }^{2}$ Instituto Geológico, Minero y Metalúrgico INGEMMET, Lima, Perú \\ *Email: sew57@cam.ac.uk
}

Accepted XX/XX/XXXX; Received XX/XX/XXXX; In original form 29/08/2019

\begin{abstract}
Orogenic plateaus can exist in a delicate balance in which the buoyancy forces due to gravity acting on the high topography and thick crust of the plateau interior are balanced by the compressional forces acting across their forelands. Any shortening or extension within a plateau can indicate a perturbation to this force balance. In this study we present new observations of the kinematics, morphology and slip rates of active normal faults in the South Peruvian Altiplano obtained from field studies, highresolution DEMs, Quaternary dating and remote sensing. We then investigate the implications of this faulting for the forces acting on the Andes. We find that the mountains are extending $\sim$ NNE-SSW to $\sim$ NE-SW along a normal fault system that cuts obliquely across the Altiplano plateau, which in many places reactivates Miocene-age reverse faults. Radiocarbon dating of offset late Quaternary moraines and alluvial fan surfaces indicates horizontal extension rates across the fault system of between 1 and $4 \mathrm{~mm} / \mathrm{yr}-$ equivalent to an extensional strain rate in the range of $0.5-2 \times 10^{-8} 1$ /yr averaged across the plateau. We suggest the rate and pattern of extension implies there has been a change in the forces exerted between the foreland and the Andes mountains. A reduction in the average shear stresses on the sub-Andean foreland detachment of $\lesssim 4 \mathrm{MPa}(20-25 \%$ of the total force) can account for the rate of extension. These results show that, within a mountain belt, the pattern of faulting is sensitive to small spatial and temporal variations in the strength of faults along their margins.
\end{abstract}

\section{Key Words:}

- Dynamics and Mechanics of Faulting, Seismicity and Tectonics, Neotectonics, Geomorphology 


\section{Introduction}

Mountain belts with low-relief, high-elevation interiors, such as the Bolivian Altiplano and central Tibet, are typically dominated by strike-slip faulting in their highest parts with little dip-slip faulting, suggesting that the crust within these ranges is neither thickening nor thinning. In contrast, the lowlands bounding their edges undergo significant shortening and crustal thickening, expressed by thrust and reverse-mechanism earthquakes [Suarez et al., 1983; Molnar and Lyon-Caen, 1988]. This pattern of deformation implies that the horizontal forces due to gravity acting on the crustal thickness contrasts between these plateaus and their bounding lowlands are balanced by the compressional forces acting across their lowlands [Dalmayrac and Molnar, 1981; Molnar and Lyon-Caen, 1988]. A powerful corollary of this argument is that, in order to start deforming a plateau interior by dip-slip faulting, or to change the style of faulting, the forces acting on the mountain belt, the material properties of the lithosphere, or the geometry of the deforming region must also change [England et al., 1988; England and Houseman, 1989].

In the Altiplano of south Peru there is geological and geomorphological evidence that the style of faulting has recently changed. Within the high plateau the active faulting is predominantly extensional along NW-SE striking normal faults that cut obliquely across the mountain belt [Sébrier et al., 1985; Mercier et al., 1992; Benavente et al., 2013] (Fig. 1). The onset of this extension is thought to be at $\sim 5-9 \mathrm{Ma}$ [Cabrera et al., 1991; Kar et al., 2016], by which time the mountain belt had reached a similar elevation to the present day [Garzione et al., 2017]. Until 6-15 Ma, 1-4 km-thick accumulations of growth strata were forming in the footwalls of major reverse faults within the Altiplano that trend sub-parallel to the active normal faults [Carlotto, 2013; Perez and Horton, 2014; Horton et al., 2015]. Therefore, the balance of forces in south Peru may have recently changed to account for the switch from reverse faulting to normal faulting in the high plateau [Sébrier et al., 1985; England and Houseman, 1989].

Some insights into why the force balance may have changed can be gained from studying the active faulting across the whole Andes. First, recent normal faulting occurs mainly in areas with average elevations higher than 3500-4000 m [Dalmayrac and Molnar, 1981; Sébrier et al., 1985; Schoenbohm and Strecker, 2009]. Normal faults have also been observed in the Western Cordillera and forearc [Sébrier et al., 1985; Mercier et al., 1992; Audin et al., 2006]. However, these faults are thought to reflect permanent deformation in response to the megathrust earthquake cycle [Saillard et al., 2017], not orogen-wide changes in the force balance persistent over millions of years. Second, the extending regions in the high mountains correlate along-strike with areas of low-angle detachment faulting in the fold-thrust belt that bounds the eastern edge of the Andes, known as the sub-Andes [Wimpenny et al., 2018]. Finally, the suggested timing for the onset of extension in the Andes correlates with a change in the location and rate of shortening in the sub-Andes at 5-9 Ma [e.g. Gubbels et al., 1993; Perez et al., 2016a]. These observations suggest that slip on weak detachment faults in the sub-Andes may have perturbed the force balance in the mountains, leading to extension in the highest part of the Altiplano [Wimpenny et al., 2018].

In this study, we present new observations of the kinematics, morphology and, for the first time, slip rates of active normal faults in the Altiplano of south Peru, between Cusco and Lake Titicaca (Fig. 1). We discuss the topography and drainage associated with the faulting, in addition to evidence of 
recent surface-rupturing earthquakes, geological indicators of the timing and rates of faulting, and the kinematics of the most active faults. Following this, we use our observations to constrain a simple physical model relating changes in the strength of the sub-Andean foreland detachment to the faulting style and deformation rate within the plateau interior.

Although the faulting between Cusco and Lake Titicaca throughout the late Quaternary has been extensional, GPS measurements made prior to the $2001 M_{w} 8.4$ Arequipa earthquake captured shortening across the same region (Fig. 1). We therefore also discuss evidence that this transient, elastic compression of the Andes due to strain accumulation on the low-angle thrusts along its margins may modulate the slip history of the normal faults within the plateau.

\section{Observations of Active Normal Faulting}

The high Andes in southern Peru form the northern-most extent of the Altiplano - a $200 \mathrm{~km}$-wide, low-relief plateau with average elevations of around $4000 \mathrm{~m}$ (Fig. 1). The earliest investigations of active faulting in the region by Suarez et al. [1983] and Sébrier et al. [1985] mapped a system of normal faults cutting NW-SE across the plateau between Cusco and Langui-Layo (Fig. 1). Extension across these normal faults was estimated to be $\sim$ N-S [Sébrier et al., 1985; Cabrera et al., 1991; Mercier et al., 1992], but there remain no estimates of the slip rates on any of these faults. More recently, Benavente et al. [2013] expanded on the fault map of Mercier et al. [1992], identifying new structures associated with metre-high scarps cutting glacial deposits that continue further south-east of LanguiLayo, towards Lagunillas (Fig. 1). The aim of this section is to use Quaternary dating of these recent scarps, in conjunction with high-resolution Digital Elevation Models (DEMs), updated mapping from optical satellite imagery and new field observations, to estimate the slip rates and recent slip vectors on the normal faults to characterise the kinematics and rate of deformation in the Altiplano plateau.

An important recent development that aides estimating the fault slip rates is the proliferation of moraine age estimates from cosmogenic radionuclide dating in the study region [Smith et al., 2005; Rodbell et al., 2009; Jomelli et al., 2014; Ward et al., 2015; D’Arcy et al., 2019]. Ice covered a large fraction of the Altiplano in the last major glacial, depositing moraines and drift sheets. Boulders on the surfaces of these moraines are typically dated to have been deposited between $\sim 10$ and $45 \mathrm{ka}$ (Fig. S1), which roughly correlates with the end of the global Last Glacial Maximum (LGM) [Clark et al., 2009]. Therefore, where scarps cut the youngest sets of fresh-looking moraines at elevations $>3500 \mathrm{~m}$, it is likely the scarp formed sometime since the LGM. However, we treat these estimates with caution, and use radiocarbon dating where possible to place more precise bounds on the scarp ages.

A number of studies have used offset Holocene and late Quaternary geomorphic features such as moraines, fan surfaces and river channels to estimate time-averaged fault slip rates and regional patterns of long-term strain. Often implicit in this methodology is that the amount of slip on a fault in the last $\sim 10-100$ ka reflects the average slip rate on the fault over many earthquake cycles. Support for this approach comes from the observation that in well-mapped areas of the continents, late Quaternary fault slip rates can account for the contemporary deformation measured by GPS [e.g. England and Molnar, 1997b; Thompson et al., 2002; Walker and Jackson, 2004]. However, there is evidence that slip rates inferred from offset landforms younger than $\sim 20$ ka can differ by orders of magnitude from 
the slip rates measured over $\sim 100-500 \mathrm{kyr}$ [Mouslopoulou et al., 2009]. Given that the offset landforms we study formed between $\sim 10-45 \mathrm{ka}$, we assume that the inferred fault slip rates are representative of the longer-term rate of fault motion. We then use the fault slip rates to study the forces controlling the long-term deformation of the continental lithosphere [e.g. England and Molnar, 1997a]. If the long-term slip rates are faster or slower than our late Quaternary slip rates, then our estimates of how the forces acting on the Andes have changed since the late Miocene will be under- or over-estimates, respectively.

Throughout this study we determine the possible range in fault slip rates, and the corresponding horizontal extension rates, by taking the appropriate combinations of the upper and lower bounds on landform age, landform offset and fault geometry. By far the largest source of uncertainty in our slip rate estimates derives from the landform age, which is equivalent to a factor of $\sim 4$, whilst the landform offset and fault geometry are typically known to within $\pm 1 \mathrm{~m}$ and $\pm 5^{\circ}$, respectively. Where possible we collect slip vector measurements and landform offsets from the centre of the fault trace to limit the effects of slip vector rotation and tapering slip rates near the fault tips [Roberts, 1996]. Another source of uncertainty on the fault slip rate includes the effect of gravity-driven slumping or soil compaction in the hangingwall, which may accentuate the measured fault throw [e.g. Di Naccio et al., 2019]. In this study, only the Tambomachay Fault reaches the surface on a steep (i.e. $>10^{\circ}$ ) slope, whilst all other scarps occur on shallowly-dipping surfaces $\left(<10^{\circ}\right)$ at the base of the fault footwall, where the effects of slope instability are negligible [Di Naccio et al., 2019]. In this setting the scarp heights are probably reflective of cumulative fault slip and not slope instability.

In the following sections we discuss observations from the active faults between Cusco and Lagunillas, traversing from the north-western end of the fault system near Cusco to the south-eastern end at Lagunillas (Fig. 1).

\subsection{Faults around the Cusco Basin}

The Cusco Basin is an E-W trending intra-montane basin filled with Pliocene and Quaternary clastic sediments situated near the northern margin of the Peruvian Altiplano [Cabrera et al., 1991] (Fig. 1, 2). Subsidence within the basin is controlled by normal faults along its northern edge, including the Qoricocha, Pachatusan, Tambomachay and Cusco Faults (Fig. 2) [Sébrier et al., 1985; Cabrera et al., 1991]. One or more of these faults is likely to have generated the earthquakes that heavily damaged Cusco in 1650 and 1950, in addition to a series of minor shocks recorded in the historical catalogue [Ericksen et al., 1954; Silgado, 1978].

\subsubsection{Qoricocha Fault}

The Qoricocha Fault reaches the surface within the mountains north of the Cusco Basin as a series of WNW-ESE trending, south-facing scarps, up to $6 \mathrm{~m}$-high, that cut glacial drift on a low-relief plateau at 4000-4350 m elevation [Cabrera and Sebrier, 1998] (Fig. 2a, 3a). The scarps can be traced for 3 $\mathrm{km}$ along-strike in a right-stepping en-echelon pattern, and probably link to the Chinchero Fault $2 \mathrm{~km}$ west of Lake Qoricocha [Cabrera et al., 1991; Benavente et al., 2013] (Fig. 2a). Although the recent scarps are prominent, they are not associated with any large-amplitude topography (e.g. footwall 
escarpments), suggesting the Qoricocha Fault has accommodated little total slip as a normal fault.

A road cut north-east of Lake Qoricocha exposes an oblique slice through the fault near its highestoffset point (Fig. 4). Within the road cut the fault scarp footwall is formed of sub-angular cobbles and gravels in a red, sandy matrix that are characteristic of the glacial deposits surrounding Cusco. The same cobble-rich layer is also exposed within the hangingwall beneath a tapered wedge of poorly-sorted dark clays, fine sands and sub-angular cobbles that thickens towards the fault scarp. We interpret the hangingwall deposits as a colluvial wedge of sediment formed by erosion of the uplifted and exposed scarp. A bulk radiocarbon sample from the base of the wedge yielded an age of 8.5-8.7 cal. kyr BP (see Table 1 and Fig. 4), which provides a minimum age for the fault offset. The typical uncertainty associated with bulk radiocarbon dating sediment is on the order of $\sim 1 \mathrm{kyr}$ due to inheritance of older or younger material within the bioturbated samples [e.g. Grützner et al., 2016], therefore the base of the colluvial wedge is roughly dated to 8-9 ka. An upper bound on the age of scarp can be estimated from assuming the glacial sediments cut by the fault were deposited during the LGM $10-45$ ka.

Given that the surface trace of the Qoricocha Fault is $<10 \mathrm{~km}$ long, it most likely ruptures in earthquakes of $M_{w} 6$ with less than a few metres of slip [e.g. Wells and Coppersmith, 1994]. Therefore the $6 \mathrm{~m}$ scarp is likely to have been formed in multiple surface-rupturing earthquakes, and the organic sediments at the base of the colluvial wedge will date from the first surface ruptures on the fault following the deposition of the glacial sediments. Taking the scarp age to be 8-45 ka, the throw rate on the Qoricocha Fault is $\sim 0.1-0.7 \mathrm{~mm} / \mathrm{yr}$.

The azimuth of the slip vector on the Qoricocha Fault is constrained to be $201^{\circ}$ (NNE-SSW) from slickenline measurements [Mercier et al., 1992] and the focal mechanism of a $M_{w} 5.2$ earthquake that generated surface ruptures on the fault in 1986 [Cabrera and Sebrier, 1998]. Using the south-dipping nodal plane of the gCMT mechanism for the 1986 earthquake with strike/dip of 121/32 [Dziewonski et al., 1981; Ekström et al., 2012], which would be consistent with the sense of slip across the scarps, the horizontal extension rate and total slip rate on the Qoricocha Fault are 0.2-1.1 mm/yr and 0.2-1.4 $\mathrm{mm} / \mathrm{yr}$, respectively.

\subsubsection{Pachatusan Fault}

The Pachatusan Fault strikes NW-SE in the mountains north-east of Cusco as $13 \mathrm{~km}$ of south-facing scarps that bound the contact between Triassic Mitu Group sandstones in its footwall, and a $4 \mathrm{~km}-$ wide, low-relief bench perched at $4000 \mathrm{~m}$ elevation in its hangingwall formed of Cretaceous sandstones and mudstones draped with lateral moraines (Fig. 2, Fig. 3b).

We generated a high-resolution DEM of the Pachatusan scarps where they cut the crests of lateral moraines using low-altitude drone photography and the structure-from-motion technique implemented in Agisoft Photoscan [e.g. Westoby et al., 2012]. Ground control points measured with differential GPS were used to guide the image matching and point cloud scaling, and we thinned and gridded the point cloud at $1 \times 1 \mathrm{~m}$ resolution using splines in tension [Smith and Wessel, 1990]. The resulting DEM highlights two sub-parallel scarps (Fig. 5a) - one running along the bedrock-moraine contact ('northern scarp') and one offset $\sim 500 \mathrm{~m}$ to the south ('southern scarp'). The scarps vertically offset the crests of the lateral moraines by up to $15 \mathrm{~m}$ (Fig. 5). Summing the vertical offsets across both 
the northern and southern scarp yields a cumulative vertical offset of $\sim 20 \mathrm{~m}$. For shallowly-dipping surfaces $\left(<10^{\circ}\right)$ that are offset by a dip-slip fault with $\sim 30-60^{\circ}$ dip, the vertical offset of the surface determined from profiles across the fault is roughly equivalent to the fault throw to within $15 \%$ [Mackenzie and Elliott, 2017]. Therefore the vertical throw across the Pachatusan Fault is probably the range $\sim 17-20 \mathrm{~m}$. Throughout this study we carefully select profiles to satisfy these constraints.

Horizontal offsets parallel to the fault strike are also evident across some of the moraine crests on the Pachatusan Fault (Fig. 5b). The NW-most moraine crest in Fig. 5b is not offset laterally within measurement precision, whilst the SE-most crest is laterally offset by $\sim 20 \mathrm{~m}$. To account for this discrepancy in the moraine crest offsets, the horizontal projection of the fault slip vector must be roughly parallel to the north-western moraine crest, which has an azimuth of $\sim 210^{\circ}$, and different to the orientation of the south-eastern moraine crest (Fig. 5c). Therefore the most recent sense of motion across the Pachatusan Fault is $\sim$ NNE-SSW extension.

The moraines at Pachatusan have not been directly dated. However, their fresh morphology implies the moraines were probably formed at the end of the LGM $\sim 10-45$ ka [Mercier et al., 1992]. Combining the cumulative fault throw and the estimated LGM age yields a throw rate of $\sim 0.4-2.0 \mathrm{~mm} / \mathrm{yr}$. Given the fault slip vector azimuth, and assuming a dip of $\sim 45^{\circ}$ [e.g. Jackson and White, 1989], the horizontal extension rate across the fault would be $0.4-2.0 \mathrm{~mm} / \mathrm{yr}$ and the fault slip rate would be 0.5-3.1 mm/yr. Notably, if the glacial deposits at Qoricocha are contemporaneous with the lateral moraines at Pachatusan, then the Pachatusan Fault may have a recent slip rate at least three-to-four times faster than the Qoricocha Fault.

\subsubsection{Tambomachay Fault}

The footwall of the Tambomachay Fault is marked by a $14 \mathrm{~km}$-long, 200-350 m-high ridge line formed of Paleocene-Eocene sandstones curving around the northern end of the Cusco Basin [Sébrier et al., 1985; Cabrera et al., 1991) (Fig. 2a). Recent slip on the Tambomachay Fault has formed south-facing normal-fault scarps along the contact between the ridge line and a low-relief hangingwall surface. Despite the normal-sense motion across the recent scarps, the Tambomachay Fault preserves a reversesense geological offset (Fig. 2b).

Near the fault's western tip, a scarp vertically offsets the crest of a lateral moraine by $3 \mathrm{~m}$ [Mercier et al., 1992] (Fig. 3c). Bulk radiocarbon dating of organic sediment collected from the colluvial wedge exposed in the scarp hangingwall returned dates between 0.9 and 8.5 cal. kyr BP, with the sample ages increasing towards the base of the wedge [Rossell, 2018]. The age of the sediment at the base of the hangingwall wedge $(8.5$ cal. kyr $\mathrm{BP})$ is similar to the sediment dated from the hangingwall of the Qoricocha Fault described above, indicating that moraine deposition ended earlier than $\sim 8-9$ $\mathrm{ka}$ (to account for the time taken to form the organic soils) and may have been relatively contiguous throughout the Cusco area. Taking a scarp age of 8-45 ka, as with the Qoricocha scarp, would yield a throw rate of $\sim 0.1-0.3 \mathrm{~mm} / \mathrm{yr}$.

Along the central section of the fault, we identified a striated bedrock fault plane exposed in building excavations that was mantled by unconsolidated sediments. The azimuth of the slickenlines were between $198^{\circ}$ and $205^{\circ}$ [similar to Mercier et al., 1992], suggesting the most recent sense of slip on 
the fault is NNE-SSW extension. Given that the fault dips $\sim 45^{\circ}$ where exposed and the rake of the slickenlines were $-90^{\circ}$, the horizontal extension rate across the Tambomachay Fault is 0.1-0.3 mm/yr and the fault slip rate is $0.1-0.4 \mathrm{~mm} / \mathrm{yr}$.

\subsubsection{Cusco Fault}

The morphology along the northern margin of the Cusco Basin changes significantly from west to east (Fig. 2). In the west, the basin's northern margin is marked by a sharp step in topography $\sim 3$ $\mathrm{km}$ south of the Tambomachay Fault. Between this topographic step and the Tambomachay Fault is an incised, low-relief surface that dips gently south, capped by alluvial sediments perched 100-300 m above the Cusco Basin floor [Cabrera et al., 1991; Carlotto et al., 2010] (marked 'incised bench' on Fig. 2a). Plio-Pleistocene alluvial and lacustrine sediments also outcrop on the lower slopes of this topographic step [Cabrera et al., 1991]. Streams draining off the elevated surface in the hangingwall of the Tambomachay Fault have incised narrow valleys into the alluvial sediments and underlying Cretaceous limestones and sandstones, however stream incision terminates abruptly at the step in topography along the northern margin of the basin.

Near Larapa the step in topography along basin's northern margin and the sharp transition in stream incision jumps northwards by $\sim 1.5 \mathrm{~km}$ and becomes coincident with the trace of the Tambomachay Fault (Fig. 2a). Eocene sandstones of the San Jeronimo group outcrop in the fault's footwall, whilst the hangingwall is draped with alluvial fans of presumed Quaternary age that grade gently towards the south into the Cusco Basin floor. There is no evidence for recent erosion of these alluvial fan surfaces. In addition, the Plio-Pleistocene sediments seen in the western portion of the basin do not outcrop in this region.

One possible interpretation of these observations is that an active, south-dipping normal fault is running along the northern margin of the basin between Cusco and Larapa (the Cusco Fault; see Fig. 2a). Recent slip on such a fault can account for the incised alluvial deposits that outcrop on the low-relief surface north-west of Larapa, in addition to the along-strike change in stream incision pattern and the topographic step along the northern margin of the Cusco Basin. However, there is no measurable offset of the Plio-Pleistocene alluvial deposits between the northern and southern margins of the Cusco Basin [Cabrera et al., 1991], suggesting that if the Cusco Fault is active, then total throw on the fault over the last $\sim 1-1.5$ Myrs must be less than $\sim 100 \mathrm{~m}$ (i.e. a throw rate $\lesssim 0.1 \mathrm{~mm} / \mathrm{yr}$ ).

Alternatively, the step in topography and perched alluvial sediments north-west of Larapa may have been uplifted during a previous shortening phase when the Tambomachay Fault accommodated reverse-sense motion [Mercier et al., 1992]. In which case, the current pattern of stream incision reflects fluvial erosion down to the Cusco Basin base level through remnant topography in the subsiding hangingwall of the Tambomachay Fault.

None of the observations presented above unambiguously require the presence of the Cusco Fault. Nonetheless, we favour the interpretation that the Cusco Fault is active, as it may account for the alongstrike changes in the morphology of the Tambomachay Fault hangingwall. Irrespective of whether the Cusco Fault is active or not, the conclusions of this paper do not rely on this interpretation. 


\subsubsection{Summary of the Normal Faulting around Cusco}

The normal faults around the Cusco Basin are 10-15 km long, strike roughly east-west, dip to the south and are separated by $\sim 5 \mathrm{~km}$ across-strike from one-another, forming a 'domino-like' array accommodating extension with an azimuth $\sim 200^{\circ}$ (NNE-SSW). The faults within the mountains north of Cusco (Qoricocha and Tambomachay Faults) are associated with metre-high Holocene scarps with an inferred late Quaternary horizontal extension rate of $\sim 0.3-1.4 \mathrm{~mm} / \mathrm{yr}$. East of Cusco, the Pachatusan Fault accommodates $\sim 0.4-2.0 \mathrm{~mm} / \mathrm{yr}$ of horizontal extension on a single fault that reaches the surface within the mountains. The Cusco Fault along the northern margin of the Cusco Basin has no Holocene scarp. If the Cusco Fault is active, then presumably it accommodates the difference in the horizontal extension rate between the faults to the north, and those to the east, of Cusco, which is equivalent to $\lesssim 0.1-1.7 \mathrm{~mm} / \mathrm{yr}$.

\subsection{Sangarara and Yanaoca Faults}

South-east of Cusco, between the towns of Sangarara and Yanaoca, lies a NNW-SSE trending, 40 kmlong intra-montane valley containing a series of perched lake basins (Fig. 1, Fig. 6). The eastern side of the valley is bound by an escarpment that has been incised by gorges draining Lakes Pampamarca and Pomacanchi (Fig. 6a). The western side of the valley is formed of lower gradient slopes with gentle river incision and a sinuous bedrock-alluvium contact.

Suarez et al. [1983] identified a $3 \mathrm{~km}$-long exposure of the Sangarara Fault north of Lake Pomacanchi separating a south-west dipping fan surface in the hangingwall from a sharp range front marked by $\sim 50 \mathrm{~m}$-high, west-facing triangular facets in the footwall (Fig. 6a). The morphology of the Sangarara Fault is consistent with recent normal-sense motion [Suarez et al., 1983; Sébrier et al., 1985].

At the head of the gorge draining Lake Pomacanchi, the Sangarara Fault is exposed between andesitic footwall rocks and hangingwall basin conglomerates that include clasts of the footwall andesites (Fig. 7a). The conglomerates have been exposed along the shoreline of Lake Pomacanchi, suggesting the base level within the basin may have recently been lowered by headward erosion through the gorge draining the lake. The exposed fault plane, which has orientation 168/36, preserves faint slickenlines in green precipitate with an azimuth of $190^{\circ}$ (Fig. 7b), implying the most recent sense of slip has been NNE-SSW extension with a component of left-lateral shear. Carlotto [2013] suggested that faults in the same area were accommodating shortening and left-lateral shear until 5-7 Ma to account for the folded Pliocene sediments in the Paruro Basin $\sim 5 \mathrm{~km}$ north of Sangarara. Therefore the recent extension at Sangarara is likely to be younger than 5-7 Ma.

Near the north-western tip of the Sangarara Fault we identified a small section of fan surface perched within the fault footwall, which has been offset relative to the hangingwall fan surface (Fig. 8). Both the footwall and hangingwall sections of the fan have been incised by streams with steep-sided channels, either due to climatic effects or base-level changes caused by downthrow of the outlet gorges (Fig. 6), causing the fan surfaces to be abandoned as drainage is routed to the valley floor. Therefore an estimate of the fan offset and its abandonment age can be used to determine the fault throw rate.

We estimated the timing of fan abandonment by bulk radiocarbon dating a $\sim 40 \mathrm{~cm}$-thick, dark brown, 
organic-rich soil layer that overlays the fan gravels (inset on Fig. 8). Two samples from the base and middle of the soil layer returned consistent dates of 7.4-7.3 and 7.4-7.2 cal. kyr BP and place a minimum age on the fan (plus a likely $\sim 1$ kyr uncertainty from the bulk soil dating approach; Table 1, Fig. 8). Given the Holocene age of the soil, the most probable cause of fan abandonment was incision due to increased stream discharge at the end of the LGM 10-20 ka [Mercer and Palacios, 1977; Seltzer, 1990; Smith et al., 2005] or the Tauca climatic wet phase 14-18 ka [e.g. Placzek et al., 2013]. Fan surfaces are also incised in the fault hangingwall near Yanaoca (Fig. 6b), which supports the proposition of climatically-controlled incision. Following fan abandonment, the $40 \mathrm{~cm}$-thick soil layer probably took a few thousand years to develop in the arid Altiplano climate [e.g. Goodman et al., 2001].

In order to determine the vertical offset of the fan surface, we generated a DEM from Pleiades bistereo panchromatic imagery using the Leica Photogrammetry Suite in Erdas Imagine [e.g. Zhou et al., 2015; Talebian et al., 2016]. The sensor and image geometry were defined using Rational Polynomial Functions, which were refined through a bundle adjustment using 30 automatically-selected and manually-edited tie points in both images [e.g. Fraser and Hanley, 2005]. The root-mean-square error between the tie points was typically $<0.3$ pixels. The resulting point cloud was averaged over $1 \times 1 \mathrm{~m}$ pixels and gridded using splines in tension [Smith and Wessel, 1990] (Fig. 8a).

An elevation profile across the fault indicates the fan surface is vertically offset by $30 \mathrm{~m}$ (Fig. 8; profile A-A'). Measurements from a barometric altimeter profile with horizontal location measured with hand-held GPS match those from the Pleiades DEM (Fig. S2). A similar fan surface to the south-east is also offset by $22 \mathrm{~m}$ (Fig. 8; profile B-B'). As the dip direction of the fan surface is perpendicular to the fault strike, and the dip angle of the fan surface is shallow $\left(\sim 10^{\circ}\right)$, then the vertical offset measured from the profile will be a good proxy for the fault throw [Mackenzie and Elliott, 2017].

Given that the minimum age of the fan abandonment is $7.2 \mathrm{ka}$, and the fan is offset by $30 \mathrm{~m}$, then the throw rate on the Sangarara Fault must be $<4.4 \mathrm{~mm} / \mathrm{yr}$. Using the fault dip and slip vector azimuth measured near Lake Pomacanchi, and taking an average fault strike of $145^{\circ}$ at the location of the offset fan, the maximum extension rate across the fault would be $<6 \mathrm{~mm} / \mathrm{yr}$ and the total slip rate would be $<10.5 \mathrm{~mm} / \mathrm{yr}$. Taking a more realistic fan abandonment age of $\sim 10-20 \mathrm{ka}$, which accounts for the time taken for the soils to develop on the fan surface, the Sangarara Fault throw rate would be $\sim 1.5-3 \mathrm{~mm} / \mathrm{yr}$, and the horizontal extension rate and slip rate would be 2.0-4.5 mm/yr and 3.6-7.9 $\mathrm{mm} / \mathrm{yr}$, respectively.

A longer-term estimate of the throw rate can also be determined from the footwall relief across the Sangarara Fault. Using the typical long-term uplift to subsidence ratio on normal faults of 1:2 to 1:3 [e.g Armijo et al., 1996], the $750 \mathrm{~m}$ of footwall relief (Fig. 6c) implies a total normal-sense fault throw of 2250-3000 m. Given the estimated timing for the onset of extension being <5 Ma [Carlotto, 2013], the Pliocene-Quaternary throw rate must be $>0.4-0.6 \mathrm{~mm} / \mathrm{yr}$, which is consistent with the estimate of the Holocene throw rate. Alternatively, if the Holocene throw rate of $1.5-3 \mathrm{~mm} / \mathrm{yr}$ were constant through time, and we assume the same uplift-to-subsidence ratio, it would take $~ 1-2$ Myrs to form the footwall relief at Sangarara.

The relief across the Sangarara Fault dies off towards the south-east near Acopia (Fig. 6), marking 
the southern tip of the $15 \mathrm{~km}$-long fault. However, a series of isolated lake basins are positioned to the south of the Sangarara Fault, indicating that dip-slip faulting continues further along the valley towards Yanoaca (Fig. 6a). Between Lake Pampamarca and Yanaoca a 10 km-long, 2 km-wide basin has been formed by subsidence in the hangingwall of the Yanaoca Fault (Fig. 6c). Exposures of the Yanoaca Fault in bedrock near Yanoaca were heavily altered, potentially due to hydrothermal fluids migrating along the fault plane from the the nearby volcanism, therefore the fault preserved no kinematic information.

Despite its subtle morphology, it is likely that the Yanaoca Fault is active. The towns of Pampamarca, Pomacanchi, Yanaoca and Tinta have all experienced severe damage in a cluster of historical earthquakes on the 18th June 1931, 5th March 1938, 23rd June 1938 and the 23rd January 1943, causing at least 100 fatalities in the sparsely populated area [Ericksen et al., 1954; Silgado, 1978].

\subsection{Faults around the Langui-Layo Basin}

The Langui-Layo Basin is a $4 \mathrm{~km}$-wide, 30-km long, NW-SE trending depression containing an intramontane lake that sits roughly along-strike to the south-east of the Sangarara and Yanoaca Faults described above (Fig. 1, Fig. 9). To date the only documented evidence of active faulting in the region is a series of E-W trending scarps following the bedrock-alluvium contact north of Langui town for $\sim 3 \mathrm{~km}$ [Sébrier et al., 1985] (Fig. 10a). These scarps mark a distinct change in the pattern of stream incision, suggesting they have been formed by a recently active, south-dipping normal fault. Nonetheless, the fault responsible for these scarps is unlikely to control the shape of the Langui-Layo Basin, as it trends oblique to the main strike of the lake and is short compared to the size of the basin.

\subsubsection{North and South Langui and East Layo Faults}

Sébrier et al. [1985] suggested a NW-SE trending, SW-dipping normal fault running along the northerneastern side of the Langui-Layo Basin may be responsible for subsidence of the lake, but did not give any evidence of the faulting. We found evidence of this fault in the mountains north-east of Layo town in the form of a $5 \mathrm{~km}$-long, 20-30 m-high, south-facing bedrock fault plane (Fig. 9a, Fig. 10b,c; East Layo Fault). Moraine deposits in the downthrown, southern wall of the fault suggest the most recent sense of motion on this fault is normal, and the bedrock fault plane preserves slickenlines with an average azimuth of $204^{\circ}$ (Fig. 10b). However, as the fault is perched high above the basin edge, it is unlikely to be dominating the current vertical motions in the Langui-Layo Basin.

Evidence of recently uplifted lacustrine deposits along the northern, southern and eastern shoreline of Lake Langui-Layo, possibly related to active faulting, also suggest that there are faults present in the region (Fig. 9a). A number of marl layers outcropping tens of metres above the current lake level, each between 3 and $6 \mathrm{~m}$ thick, contain well-preserved bivalve and gastropod fauna, often in shelly lag horizons. South of Layo town two sub-horizontal layers of the marls are particularly well exposed $50 \mathrm{~m}$ and $60 \mathrm{~m}$ above the current lake level in the incised edge of a river bank (Locality M2 on Fig. 9a; Fig. S3). The stratigraphy, fossils and sedimentary structures in the exposure are typical of a near-shoreface, sub-aqueous depositional environment. There are two possible explanations for these sediments now being at least $60 \mathrm{~m}$ above the lake level: (1) the lake was previously higher, or (2) there 
has been vertical motion of these deposits relative to the lake level caused by active faulting.

For the lake to be previously higher than today would require the outflow at the north-western edge of Lake Langui-Layo was at least $50 \mathrm{~m}$ higher than present. However, we found no morphological evidence of an incised sill (e.g. landslide or moraine dams) near current the lake outlet, which flows through a wide U-shaped valley.

Alternatively, there may have been vertical motions caused by faulting that either lowered the outlet or raised the shorelines of the lake relative to its past level. The linearity of the shorelines, and the steepening of the lateral moraine crests towards the lake shores, are suggestive of buried active normal faults along the lake edge, which could account for the relative uplift of marl deposits at localities M1 and M3 (Fig. 9; North and South Langui Faults). However, we were unable to measure the slip rate on these faults without an estimate of the age of the marl deposits and their depth of deposition.

\subsubsection{Vilacota Fault}

The Vilacota Fault reaches the surface in the east of the Langui-Layo Basin (Fig. 9a) as $\sim 20 \mathrm{~km}$ of EW trending, south-facing scarps cutting lateral moraines and glacial drift deposits along the southern edge of a 200-700 m-high footwall escarpment (Fig. 10d,e). The sense of motion across the recent scarp is uplift to the north, which is consistent with uplifting the high mountains of the Vilacota Range, the marl deposits at locality M2 and the back-tilted, low-relief surface south-east of Layo town (Fig. 9).

We generated a DEM of the Vilacota Fault scarp using Pleiades bi-stereo panchromatic imagery and the same methods described in Section 2.2, with the resulting point cloud gridded at a slightly coarser $2 \times 2 \mathrm{~m}$ resolution (Fig. S4). Along the western section of the fault, the normal-faulting scarps cutting the crests of lateral moraines are between 7 and 13 m-high (Fig. 10d, Fig. S4). Along the fault's eastern section, the scarps are smaller, between 3 and $5 \mathrm{~m}$-high, and cut through recent glacial and landslide deposits in a U-shaped glacial valley $100 \mathrm{~m}$ south of the Vilacota Range front (Fig. 10e, Fig. $\mathrm{S} 4)$. It is possible that recent erosion or deposition in the hangingwall axial valley may have erased evidence of earlier scarps along the eastern section of the fault.

We used the variations in the fault plane orientation near the Vilacota Fault's western tip to reconstruct the slip vector. Active normal faults that have been exposed by excavation are often corrugated, with the slickenlines sub-parallel to these corrugations [Jackson and McKenzie, 1999]. As a result, the corrugated planes will all contain the fault slip vector. We found that all of the fault plane measurements contain a common vector of $\sim 192 / 64$ (Fig. 10d, inset), which indicates the Vilacota Fault has a NNE-SSW orientated slip vector, sub-parallel to the fault slip vectors at Cusco and Sangarara.

No direct dating is available from Vilacota, though assuming the scarps formed following moraine deposition in the LGM would yield a speculative throw rate of $\sim 0.1-1.3 \mathrm{~mm} / \mathrm{yr}$. Using measurements of the fault plane strike and dip (130-140/60-70), the horizontal extension rate on the Vilacota Fault would be $0.1-0.8 \mathrm{~mm} / \mathrm{yr}$ and the fault slip rate would be $0.1-1.6 \mathrm{~mm} / \mathrm{yr}$. 


\subsection{Parina Fault}

The Parina Fault is situated $\sim 70 \mathrm{~km}$ south of Ayaviri and represents a marked across-strike jump in the NW-SE trending fault system cutting across the mountain belt (Fig. 1, Fig. 11). The surface trace of the fault follows the contact between a 100-150 m-high, incised footwall escarpment formed of Oligo-Miocene volcaniclastic rocks and a 1-2 km-wide Quaternary hangingwall basin (Fig. 11). Along the southern section of the fault, Holocene scarps outcrop along the footwall-basin contact (Fig. 12). The morphological features at Parina are typical of the other normal faults between Cusco and LanguiLayo discussed earlier, but are generally more subdued. For example, the footwall relief at Parina is less than half that of the Tambomachay, Cusco and Sangarara Faults, suggesting the Parina Fault has accommodated less total slip (assuming their footwalls are equally erodable). In addition, off-fault deformation preserved as scarps with the same kinematics as the Parina Fault, but outcropping in the uplifted footwall (Fig. 12c,d), implies that recent deformation may not be localised onto a single discrete structure.

The southern section of the Parina Fault ruptured in a $M_{w} 6.1$ normal-faulting earthquake in 2016 [Wimpenny et al., 2018]. Twelve kilometres of 10-30 cm-high surface ruptures were mapped south of Lake Saguanani that are coincident with NW-SE trending, metre-high scarps cutting through bedrock and the overlying moraine cover. We generated two DEMs of the Parina scarps using low altitude drone-based imagery - one along the northern section of the fault near Lake Saguanani, and one along the southern section of the fault south-east of Parina village (Fig. S5; see discussion in Section 2.1.2 for details on the DEM construction method). Near Lake Saguanani, the scarps vertically offset the crests of lateral moraines by between 2 and $9 \mathrm{~m}$ and reverse the local slope direction, but preserve no evidence for lateral offsets (Fig. S5). Assuming a LGM age for the moraines and scarps would yield a speculative fault throw rate between 0.1 and $0.9 \mathrm{~mm} / \mathrm{yr}$. Taking the dip and rake determined by Wimpenny et al. [2018] for the Parina earthquake fault plane (40/-100), the throw rate would equate to an extension rate of $0.1-1.1 \mathrm{~mm} / \mathrm{yr}$ and a fault slip rate of $0.1-1.4 \mathrm{~mm} / \mathrm{yr}$.

The direction of extension across the Parina Fault is constrained by both field slip vector measurements (Fig. 12e) and modelling of the 2016 earthquake to be $235-245^{\circ}$ (NE-SW) [Wimpenny et al., 2018]. In addition, along the northern section of the fault, between Ocuviri and Lake Saguanani, an exposure of bedrock fault plane perched $70 \mathrm{~m}$ above the hangingwall basin preserves the sense of recent fault slip with slickenlines that have azimuths between $222^{\circ}$ and $216^{\circ}$ (Fig. 12a). The same fault plane also preserves a reverse-sense geological offset between Cretaceous rocks in the hangingwall and OligoMiocene rocks in the footwall (Fig. 12a). Combined, these observations suggest that the region around Parina was shortening at some time since the mid-Miocene, and that the Parina Fault has been reactivated as a normal fault. Using the footwall relief $(\sim 100-150 \mathrm{~m})$ and an uplift-to-subsidence ratio of 1:2-3 [e.g. Armijo et al., 1996] the total fault throw is likely to be on the order of 300-600 m. Given the throw rate of 0.1-0.9 mm/yr, the Parina Fault may have started accommodating extension sometime between 0.5 and 6 Ma. 


\subsection{Faults around Lake Lagunillas}

\subsubsection{North and South Lagunillas Faults}

Lake Lagunillas is a $17 \mathrm{~km}$-long, $5 \mathrm{~km}$-wide intra-montane lake that lies $\sim 50 \mathrm{~km}$ south-east of Parina (Fig. 1, 13). No active faults have previously been mapped in this area, though a number of the geomorphic features recognised from the active normal faults at Cusco, Sangarara and Langui-Layo are also apparent at Lagunillas. For example, the linearity of the lake's northern shoreline, the asymmetry of the topography either side of the lake, and the rivers draining the lake to the north that are incising deep gorges into bedrock all suggest the northern shore may be fault bounded (Fig. 13; North Lagunillas Fault).

Towards the south-eastern end of Lake Lagunillas both the northern and southern shorelines become lobate and the lake narrows (Fig. 13). In the same area, a $9 \mathrm{~km}$-long, south-west facing scarp trends sub-parallel to the southern shoreline of the lake and reverses the local slope (Fig. 14a; South Lagunillas Fault). SRTM $30 \mathrm{~m}$ topography reveals the scarp is around $40 \mathrm{~m}$ high (Fig. 14b), therefore uplift in the footwall of this fault may also account for the narrowing shoreline at the southern end of Lake Lagunillas. As the fault reverses the local slope direction and is associated with no large-amplitude topography, the South Lagunillas Fault is likely to have accommodated little total slip.

\subsubsection{Ululunasa and Willa-Willa Faults}

Two kilometres east of Lake Lagunillas a set of south-facing, WNW-ESE trending scarps connect to a prominent $\sim 15$ m-high bedrock fault plane damming Lake Ululunasa's northern shore (Fig. 13, 14c). This bedrock fault plane occurs along the base of a 100-150 m-high footwall escarpment formed of Paleocene conglomerates (Fig. 14c). A $10 \mathrm{~m}$-wide wind gap cut into the footwall is elevated $\sim 5 \mathrm{~m}$ above the current lake level and marks the old course of the lake outlet, suggesting the lake basin has been downthrown in the hangingwall of a south-dipping normal fault (Fig. 14c). The bedrock fault plane did not preserve any slip-direction indicators. Assuming the footwall ridge line has been uplifted following the onset of extension $\sim 5 \mathrm{Ma}$, and taking a footwall-uplift-to-hangingwall-subsidence ratio of between 1:2 and 1:3, would yield a speculative fault throw rate on the order of $\sim 0.06-0.1 \mathrm{~mm} / \mathrm{yr}$.

Fifteen kilometres south-east of Lake Ululunasa, the Willa-Willa Fault is expressed as a $\sim 20 \mathrm{~km}$-long, NW-SE trending, south-west facing scarp cutting across the Willa-Willa Range (Fig. 13). At the fault's south-eastern tip, the normal-faulting scarp reverses the local slope direction, causing incision in the uplifting footwall and forming sag ponds dammed against the scarp in the downthrown hangingwall (Fig. 14d,e). The scarp preserves two distinctly different vertical offsets. Along the crests of parallel spurs the vertical offset is $\sim 5-15 \mathrm{~m}$, whilst within the intervening valleys the scarp is significantly smaller, around $\sim 1-2 \mathrm{~m}$ high (Fig. 14d,e). We interpret these differences to reflect the preservation of the older, cumulative scarp on the spur crests, whilst within the intervening valleys the older scarp has been eroded, preserving only the more recent surface offsets. As the scarp is not associated with any large-amplitude topography and reverses the local slope, it is expected that the Willa-Willa Fault has accommodated little slip as a normal fault. 


\subsection{Huambo-Cabana Conde Faults}

On the southern edge of the Peruvian Altiplano, between the northern flank of Sabancaya Volcano and the Colca Canyon (Fig. 1), Sébrier et al. [1985] identified $28 \mathrm{~km}$ of E-W trending, south-facing normal fault scarps that offset recent lava flows by 10-30 m. These scarps, collectively known as the Huambo-Cabana Conde Faults, preserve slickenlines with a $190^{\circ}$ azimuth [Mercier et al., 1992].

Between 2002 and 2013 three moderate-magnitude earthquakes and a swarm of micro-seismicity occurred within the Huambo-Cabana Conde Fault Zone. Jay et al. [2015] used InSAR and regional seismic data to suggest that the $M_{w} 5$ earthquakes ruptured north-dipping normal faults between 0 and $8 \mathrm{~km}$ depth and that reached the surface $\sim 5 \mathrm{~km}$ south of the faults mapped by Sébrier et al. [1985]. Both Sébrier et al. [1985] and Jay et al. [2015] attributed the kinematics of these faults to a regional pattern of $\sim \mathrm{N}-\mathrm{S}$ extension throughout the northern Altiplano. The depth of slip in the 2002-2013 earthquakes, and the 10-15 km length of some of the fault surface traces, has been used to support the view that the Huambo-Cabana Conde Faults are accommodating téctonic extension throughout the seismogenic crust. However, it is possible that the extension direction across the Huambo-Cabana Conde Faults is influenced by the differential stresses in the crust due flank collapse of Sabancaya Volcano into the 3000 m-deep Colca Canyon [e.g. Miller and Dunne, 1996], and their slip vectors do not accurately reflect deformation in response to regional tectonic motions. For this reason, we do not consider the kinematics and slip rates on these faults further.

\subsection{Summary of Faulting in the South Peruvian Andes}

The faults described in this study form a 20-40 km-wide, right-stepping en-echelon band trending NWSE obliquely across the Peruvian Altiplano. Individual fault segments are between 10 and $20 \mathrm{~km}$ long, strike between E-W and NW-SE and have a predominantly south-westwards dip. The fault lengths are similar to the seismogenic thickness in the area estimated from earthquake source mechanisms [Devlin et al., 2012; Wimpenny et al., 2018].

The recent sense of slip on all of the faults is extensional with a varying component of left-lateral shear, and the faults consistently accommodate motion along slip vectors that are sub-parallel to the shortening direction in the adjacent sub-Andean forelands, irrespective of the fault strike (Fig. S6; see also Wimpenny et al. [2018]). Near Cusco, this is manifest as NNE-SSW extension on mainly E-W striking faults, whilst near Parina the faulting is NE-SW extension on NNW-SSE striking faults. Repeat measurements of slickenlines in the field, and a comparison between the Parina earthquake slip vector measurements with seismology and InSAR modelling, indicate the slip vector azimuths are accurate to within $\pm 5^{\circ}$.

Previously published measurements of fault slip vectors in south Peru are consistent with our inferred $\sim$ NNE-SSW direction of extension near Cusco [Sébrier et al., 1985; Mercier et al., 1992]. Further south, near Lake Titicaca, our inferred NE-SW direction of extension is roughly consistent with the predominantly $\sim \mathrm{N}-\mathrm{S}$, but also $\sim \mathrm{NE}-\mathrm{SW}$, slip vectors measured on minor faults within the shallow sedimentary cover of the Eastern Cordillera by Mercier et al. [1992] and Bellier [1989]. Some of the variability between our slip vector measurements and those of Mercier et al. [1992] may result from 
weak horizons within the sedimentary basins decoupling the shallow sediments from deformation in the underlying basement [e.g. Cornet and Röckel, 2012]. As a result, we consider our estimates of the extension direction as being more representative of the regional strain than those of Mercier et al. [1992] near Lake Titicaca, as we have used the slip direction recorded on bedrock exposures of normal faults that have accommodated hundreds of metres of total slip, rather than faults contained solely in the sedimentary cover with a few metres of slip.

Our field measurements of fault slip vectors are also generally consistent with the kinematics of wellconstrained earthquake focal mechanisms with $M_{w}>5.5$ in south Peru (Fig. 1). However, there is significant variability in the strikes of the nodal planes and slip vectors of the focal mechanisms of $M_{w}<5.5$ earthquakes. Part of this variability results from the earthquake mechanisms of low $M_{w}$ 5 events being derived from long-period surface wave observations, which have limited sensitivity to the components of the moment tensor equivalent to vertical dip-slip for shallow $(<10 \mathrm{~km})$ centroid depth events [Dziewonski et al., 1981]. In addition, many of the low $M_{w} 5$ earthquakes are unlikely to have ruptured the full, 10-15 km-thick seismogenic layer, therefore will not be representative of the dominant strain in the region [e.g. Brune, 1968]. In contrast, earthquakes that break the full seismogenic layer (i.e. $M_{w}>5.5$ ) match the field measurements of fault slip vectors to within $\pm 5^{\circ}$, as they reflect the dominant crustal strain in the region/and have been derived using the more accurate methods of teleseismic body-waveform modelling or radar geodetic measurements [e.g. Devlin et al., 2012; Wimpenny et al., 2018].

The Tambomachay, Pachatusan and Parina normal faults reactivate structures that preserve a reversesense geological offsets. Similarly, the trend of all the normal faults follows the predominantly NW-SE trend of Miocene reverse faults in the Peruvian Altiplano [Perez et al., 2016b], implying that the preexisting structural fabric has been important in localising the recent extensional strain. Reactivation of north-eastward (i.e. foreland-ward) verging thrusts could also account for the consistently southwestward dip of the active normal faults. Where the timing of last major crustal shortening episode has been constrained, it is typically $\sim 6-15 \mathrm{Ma}$ [e.g. Carlotto, 2013; Horton et al., 2015], placing the recent extension as post-Miocene in age. Extrapolating the throw rates on faults where there is good age control implies the current footwall relief on these faults formed in the last 1-6 Myrs. The postMiocene extension along reactivated reverse faults in south Peru mirrors the pattern and timing of deformation seen on the southern edge of the Puna plateau in the Argentinian Andes [e.g. Schoenbohm and Strecker, 2009].

Age control was only available for the faults around Cusco and Sangarara. At both these localities the cumulative horizontal extension rate across the whole normal-fault system is in the range $\sim 1-4 \mathrm{~mm} / \mathrm{yr}$ (Table 2). It is unlikely the cumulative extension rate is much larger than $4 \mathrm{~mm} / \mathrm{yr}$, as extension rates in the plateau would then exceed the shortening rate in the sub-Andes [e.g. Oncken et al., 2012]. Between Langui-Layo and Lagunillas there is no robust age control on the fault offsets. However, the Vilacota and Parina Faults offset lateral moraine deposits that probably date to the Last Glacial Maximum ( 10-45 ka) by 5-10 m, yielding speculative extension rates $\lesssim 1 \mathrm{~mm} / \mathrm{yr}$ (Table 2 ). We were not able to make any estimates of the extension rates across the faults near Lagunillas at the southeastern end of the study area, though based on the subtle morphological expression of faulting in this region the extension rates are expected to be small (i.e. $\lesssim 1 \mathrm{~mm} / \mathrm{yr}$ ). 


\section{Discussion}

\subsection{Preservation and Morphology of Normal Faulting in south Peru}

A number of the normal faults discussed above were identified on the basis of metre-high fault scarps that occur in the mountains, perched above the local base level, and with no associated large-amplitude topography. A prime example is the spectacular scarps on the Qoricocha Fault (Fig. 3a). At first glance, the Qoricocha Fault may appear to be the dominant structure accommodating deformation in the area on the basis of the $6 \mathrm{~m}$-high, fresh-looking scarp cutting an otherwise undisturbed surface. However, this fault has been uplifted relative to the Cusco Basin floor by larger vertical motions on the Tambomachay and Cusco Faults over the late Quaternary (<1 Ma). Unlike in the mountains, on the basin-bounding faults earthquake scarps are rarely preserved due to deposition in their hangingwalls and incision in their footwalls. Therefore, well-preserved fault scarps are not an accurate indicator of the long-term fault activity or the relative slip rates of faults in south Peru. The Qoricocha scarps are probably exceptionally preserved due to the recent deposition of glacial sediments and their subsequent abandonment in a low erosion rate environment.

A more accurate indicator of fault activity throughout the late Quaternary is the footwall relief and the pattern of stream incision across the fault trace. For example, sharp changes in river incision and the relief across the Cusco, Sangarara and Yanoaca Faults make them identifiable in the field. However, the pattern of stream incision is only preserved because their hangingwall basins remain isolated from headward erosion along the Vilcanota River valley, which drains into the Amazon Basin. In places where headward erosion has scoured the hangingwall basins of normal faults, such as the western portion of the Anta Basin west of Cusco, the sharp transition in stream incision is no longer preserved, and the presence of normal faulting is more difficult to identify (as seen for the normal faults in Central Italy [D'Agostino et al., 2001]). Nonetheless, subtle triangular facets and 'wineglass canyon' incision patterns do remain, though these features cannot easily be used to reconstruct fault slip rates.

Another key indicator of fault activity is the height of normal fault's footwall escarpment, which is partly controlled by the footwall lithology, and therefore also subject to preservation bias [e.g. Goldsworthy and Jackson, 2000]. An excellent example of this preservation bias is seen at Sangarara (Fig. 6). Suarez et al. [1983] identified a $\sim 3$ km-long section of the Sangarara Fault associated with 50 m-high triangular facets separating graded fan surfaces from the steep, incised footwall escarpment (see Fig. 8a). Along-strike of this well-preserved section, the fault morphology changes significantly. One kilometre north of Lake Pomacanchi, the Sangarara Fault has no triangular facets, but a rounded range front with little change in the pattern of stream incision across the bedrock-alluvium contact. The transition in the fault morphology correlates with a geological contact between Paleocene sandstones in the well-preserved section of the footwall, and a mixture of Cretaceous limestones, shales and evaporites forming the poorly-preserved section of the footwall [Carlotto et al., 2009].

From the discussion above, it is clear that the preservation of normal faulting in south Peru is highly variable. As a result, there may be parts of the study area not discussed so far where active normal faulting is taking place, most likely in the areas between the mapped faults, kinematically linking them together. One particular region is west and south of Cusco, where deep canyons cut by tributaries of 
the Apurimac River could have incised through the uplifting footwalls and subsiding hangingwalls of most faults, if present, leaving little detectable trace of active faulting.

At the south-eastern end of the fault system near Lagunillas, many of the faults (e.g. Willa Willa, South Lagunillas Faults) reverse the local slope direction and are associated with no significant footwall escarpments. These morphological traits may reflect reduced amounts of slip on the south-eastern end of the fault system as the extension dies out, which would be consistent with the limited recent extension in the Bolivian Altiplano [e.g. Mercier et al., 1992; Lamb and Hoke, 1997; Lamb, 2000]. As the Bolivian Altiplano is on average 400-500 m lower elevation than the PeruvianAltiplano, the alongstrike decrease in the extension may be a product of the decreasing gravitational body forces acting on these different sections of the mountain range [e.g. England and Molnar, 1997a]. Alternatively, the subdued normal fault morphology could reflect recent activation of the faults near Lagunillas, or that the extension becomes more distributed in this region.

\subsection{Dynamical Implications: Decrease in the Shear Forces Supported by the Sub- Andean Detachment}

Active normal faults in Peruvian Altiplano that reactivate Miocene age reverse faults are evidence that the force balance in the mountain belt, when averaged over multiple earthquake cycles, has changed in the last 5 Myrs [e.g. Dalmayrac and Molnar, 1981; England and Houseman, 1989]. Prior to the onset of extension, it is likely that a balance between the forces acting on the boundary of the mountains and buoyancy forces did exist, leading to the formation of the high-elevation, low-relief Altiplano plateau [Molnar and Lyon-Caen, 1988].

The orientation and timing of slip on the normal faults suggests that the recent extension is a response to a decrease in the forces transmitted across the range front in the sub-Andes [Wimpenny et al., 2018]. In particular, the high Andes are extending parallel to the shortening direction in the sub-Andes, and parallel to gradients in the topography on the eastern margin of the mountain belt. Our measurements of the normal fault slip rates can be used to place bounds on the decrease in the forces transmitted across faults in the sub-Andes using a two-dimensional, static force balance [modified from Lamb, 2006] (Fig. 15). A two-dimensional geometry is appropriate, as the measured slip vector azimuths on the normal faults are parallel (within $\pm 10^{\circ}$ ) to the direction of shortening in the sub-Andes, with little evidence for motion along-strike the mountain belt. A moment-tensor summation of the shallow crustal earthquakes shown in Fig. 1 confirms this pattern, with across-strike extension accommodating $\sim 20$-times greater strain than along-strike shear. Therefore it is only necessary to consider forces acting vertically and perpendicular to the strike of the mountain belt to account for $95 \%$ of the recent deformation [Dalmayrac and Molnar, 1981]. A static model is appropriate as the finite extensional strain accommodated by the normal faults is small ( $\lesssim 1 \%$; Sébrier et al. [1985]), therefore changes in the crustal thickness and the geometry of the Andes has probably had little effect on the force balance since the extension began.

Three dominant forces act on the sub-Andes: (1) the weight of the crust overlying the detachment fault ( $M g$ on Fig. 15), (2) the shear force supported by the detachment ( $F_{s}$ on Fig. 15), and (3) the horizontal force acting on the back of the sub-Andes $\left(F_{f}\right.$ on Fig. 15). All three must be in a quasi- 
static balance, therefore it is possible to write an expression for the shear force on the sub-Andean detachment [Lamb, 2006]:

$$
F_{s}+M g \sin \theta-F_{f} \cos \theta=0
$$

where $\theta$ is the dip of the detachment. The force acting on the back of the sub-Andes $F_{f}$ will be equivalent to the sum of the buoyancy forces resulting from horizontal differences in vertical normal stress $\Delta \sigma_{z z}$ between the mountains and the adjacent forelands [Dalmayrac and Molnar, 1981], and any differential stresses $\Delta \sigma$ resulting from deformation within the mountains:

$$
F_{f}=\int_{0}^{L} \Delta \sigma_{z z} d z+\int_{0}^{L} \Delta \sigma d z
$$

where $L$ is the thickness of the crust above the down-dip edge of the detachment (Fig. 15). Together, Equations 1 and 2 link the shear forces supported by faults on the edge of a mountain belt to the differential stresses within its interior.

Prior to the onset of extension, the differential stresses within the interior of the plateau were probably negligible (i.e. the second term in Equation 2 was approximately zero), to satisfy the conditions required to form a wide and low-relief plateau [Molnar and Lyon-Caen, 1988]. Therefore, to account for the recent normal faulting, either the buoyancy forces have increased, $M g$ has decreased or $F_{s}$ has decreased (see Equations 1 and 2). As the buoyancy forces are set by the thickness and density of the crust in the Andes and South American forelands, and crustal thinning caused by the recent extension in south Peru is $\ll 1 \%$, the buoyancy forces are likely to have remained approximately constant over the last $\sim 5$ Myrs. Similarly, $M g$, which is controlled mainly by the area of the sub-Andean wedge, is unlikely to have decreased recently, as material is constantly being incorporated into the fold-thrust belt. Therefore, the most likely explanation for the onset of recent extension is a reduction in the shear strength of the sub-Andean detachment $F_{s}$.

Following a decrease in the shear force on the detachment $\delta F_{s}$, the crust at the back of the sub-Andes would be subject to a force perturbation $\delta F_{s} / \cos \theta$. This force will be supported in the plateau by work done by frictional slip on faults in the brittle crust, and viscous deformation within the underlying ductile crust. The frictional resistance to deformation can be expressed as: $\Delta \sigma_{f}=2 \mu^{\prime} \rho g z /\left(1+\mu^{\prime}\right)$, where $\mu^{\prime}$ is the effective coefficient of friction on normal faults dipping at $45^{\circ}$ and $\rho$ is the average crustal density [Turcotte and Schubert, 2002]. To estimate the viscous resistance to deformation, we make the simplification that there is little vertical variation in the horizontal velocity of ductile crustal flow $\left(\partial u_{x} / \partial z \approx 0\right)$, as the shear stresses on the base of the Altiplano are likely to be small, and we ignore any vertical component of the velocity field associated with flow around the edge of the underthrusting Brazilian Shield $\left(u_{z} \approx 0\right)$ [e.g. Bendick et al., 2008]. These simplifications are equivalent to the thin-viscous sheet approximation [e.g. England and McKenzie, 1982]. If the ductile crust has some average Newtonian viscosity $\eta$ the viscous resistance to deformation is given by: $\Delta \sigma_{v}=2 \eta \dot{\varepsilon}$, where $\dot{\varepsilon}$ is the strain rate. Using this model of the rheology beneath the Andes we can use Equations 1 and 2 to write an expression for the extensional strain rate in the ductile crust as a function of the 
drop in shear force supported by the sub-Andean detachment:

$$
\begin{aligned}
\delta F_{s} & =\left(\int_{0}^{T_{s}} \Delta \sigma_{f} d z+\int_{0}^{L-T_{s}} \Delta \sigma_{v} d z\right) \cdot \cos \theta \\
& \approx \frac{\mu^{\prime}}{1+\mu^{\prime}} \rho g T_{s}^{2}+2 \eta \dot{\varepsilon}\left(L-T_{s}\right),
\end{aligned}
$$

where $T_{s}$ is the depth over which faults support shear stresses by frictional resistance in the brittle crust and we have assumed that $\cos \theta \approx 1$ as $\theta \lesssim 10^{\circ}$ (Fig. 15).

The thickness of the deforming crust at the back of the sub-Andes, $L$, is equivalent to $W \sin \theta+h$, where $W$ is the down-dip width of the underthrusting Brazilian Shield and $h$ is the height of the mountains. The horizontal extent of underthrusting beneath the Peruvian Andes has been estimated from gravity measurements [Fan et al., 1996], shortening estimates in the sub-Andes [Kley, 1996] and surface wave tomography [Ma and Clayton, 2014] to be $\sim 100-200 \mathrm{~km}$. The dip of this interface is taken to be $\sim 7-10^{\circ}$ based on the mechanisms of thrust-faulting earthquakes beneath the sub-Andes [Emmerson, 2007] and the average height of the mountains $h$ is taken as $4 \mathrm{~km}$. Using these geometrical constraints, $L \approx 16-39 \mathrm{~km}$.

The average viscosity of the crust in the Andes has been estimated from the relationship between topography and deformation rates to be $\sim 10^{21}-10^{22} \mathrm{~Pa}$ s [Lamb, 2000; Husson and Ricard, 2004]. These values are typical for vertically-averaged crustal viscosities in mountain belts [e.g. Flesch et al., 2001]. Earthquake source models indicate the brittle crust in the Altiplano $T_{s}$ is $\sim 10 \mathrm{~km}$ thick [Wimpenny et al., 2018], and we assume that the normal faults have $\mu^{\prime} \lesssim 0.2$ [Copley, 2017].

Calculating the extensional strain rate in the Peruvian Altiplano from fault slip rates requires some assumptions regarding the distribution of the deformation as a function of depth. It is possible that the extension rates on each individual fault are not constant down-dip, as slip may become partitioned as a function of depth in systems of closely-spaced normal faults [e.g. Finocchio et al., 2016]. Nonetheless, the cumulative extension across the entire fault system is constant as a function of depth, which is the measurement key to our modelling.

The discontinuous fault slip rates measured at the surface probably reflect a more continuous pattern of deformation within the underlying ductile crust [Molnar, 1988]. Therefore, by spatially-averaging the fault slip rates, one can recover the horizontal components of the strain rate field in the ductile layer [Haines and Holt, 1993; England and Molnar, 1997b]. The majority of the recent deformation in south Peru has been plane strain in a vertical cross-section perpendicular to the mountain belt, with normal faulting mapped between the Eastern and Western Cordilleras (Fig. 1). Therefore an appropriate length-scale to average the velocity gradients over is the width of the plateau $(\sim 200$ $\mathrm{km}$ ). Given the 1-4 mm/yr of cumulative extension across the normal faults described above, the late Quaternary extensional strain rate across the plateau would be in the range of $0.5-2 \times 10^{-8} 1 / \mathrm{yr}$. If the extensional strain in the ductile crust is concentrated into the $\sim 20-40 \mathrm{~km}$ around the Cusco-Lagunillas Faults, the local strain rate estimates would be $\sim 5$ to 10 times higher, implying an underlying weak zone. Nonetheless, the average deformation rates across the plateau would remain the same. Further measurements of fault slip rates in south Peru will help refine this picture beyond our simple uniform strain assumption. 
Given the constraints on the rheology and geometry of the model discussed above, a reduction in the shear force on the sub-Andean detachment by $\delta F_{s} \lesssim 0.46-0.95 \mathrm{TN} / \mathrm{m}$ would generate the observed extension rate across the Peruvian Altiplano. This value is equivalent to an average shear stress change $\delta \tau \lesssim 4 \mathrm{MPa}$ (Fig. 16a). The differential stresses acting on the back of the sub-Andes as a result of this change would be $\lesssim 24-28 \mathrm{MPa}$. The average shear stresses on the detachment determined from similar force balance methods are between 15 and $20 \mathrm{MPa}$ [Lamb, 2006; Oncken et al., 2012], therefore the fractional change in the shear strength of the detachment is $\lesssim 20-25 \%$. We consider this estimate to be an upper bound, as it is likely the long-term strength of brittle crust within the Altiplano is smaller than estimated using the depth of earthquake rupture models [e.g. Jackson, 2002]. Nonetheless, the key result of these calculations is that a small change in the forces transmitted across faults on the margin of a mountain belt can have a significant effect on the rate and style of faulting within its interior, because of the delicate balance of forces in this setting.

A range of different processes could account for a decrease in the shear force supported by the faults on the eastern margin of the Andes. If the shallow (0-20 km), seismogenic portion of the detachment has a frictional rheology described by: $\tau=\mu^{\prime} \sigma_{n}$, where $\sigma_{n}$ is normal stress and $\mu^{\prime}$ is the effective friction, the necessary weakening could be caused by decreasing the intrinsic frictional strength or increasing the pore-fluid pressures on the fault (Fig. 15b, inset). Either could result from the thrust front advancing onto overpressured or clay-rich sediments in the foreland basin. It is also possible that increasing the thermal gradient along the detachment could have reduced the down-dip width of frictional coupling $W_{f}$, reducing the forces transmitted between the foreland and the Andes. Calculations for the frictional shear force on the sub-Andean detachment demonstrate that changing either $\mu^{\prime}$ or $W_{f}$, even by a small amount (dependent on the initial $\mu^{\prime}$ and $W_{f}$ ), can easily account for the perturbation to the force balance inferred from the faulting observations (see arrows on Fig. 16b). Alternatively, part of the detachment may have a viscous rheology of the form: $\tau=A \dot{\varepsilon}^{1 / n}$, where $A \propto e^{1 / T}$ is a material property dependent on temperature $T$ and $n$ is the stress exponent [e.g. Ranalli, 1995]. Small increases in the temperatures along the detachment, or the incorporation of new material with a lower creep strength, could also account for the change in the force balance. However, from the observations of normal faulting alone, it is not possible to determine which of these particular mechanisms may have caused the strength of the detachment to decrease in the forelands of south Peru.

\subsection{Transient Stress and Strain Across the Cusco-Lagunillas Faults}

In addition to changes in the force balance in the Andes over the last 5 Myrs, there is also evidence from GPS and earthquake observations spanning the $2001 M_{w} 8.4$ Arequipa earthquake that the force balance changes every few hundred years due to the accumulation and release of elastic strain in megathrust earthquakes along the margins of the mountain belt.

GPS measurements collected between 1993 and 2000 captured $\sim 9 \mathrm{~mm} / \mathrm{yr}$ of NE-SW shortening across the Peruvian Altiplano (Fig. 17a), which is opposite to the sense of late Quaternary strain on the Cusco-Lagunillas Fault system. Seismicity in the Peruvian Altiplano over the same time period consisted of three low $M_{w} 5$ normal-faulting earthquakes (Fig. 17d,e). Given that there is no evidence of reverse faulting within the plateau, it is likely the shortening captured by the GPS data reflects the accumulation of elastic strain in the brittle crust caused by frictional locking on the adjacent megathrust 
faults [Bevis et al., 2001]. Other sources of transient deformation that may affect GPS measurements, such as solid earth tides, hydrological loads and visco-elastic relaxation following glacial unloading or large earthquakes [e.g. Bird and Carafa, 2016] cannot account for the long-wavelength pattern of E-W shortening.

Coseismic and postseismic slip on the megathrust in the Arequipa earthquake reversed the interseismic motions at many of the GPS stations (Fig. 17a,b). In particular, stations MDRG and MACU captured $216 \mathrm{~mm}$ of NE-SW extension across the Cusco-Lagunillas Fault system between 1999 and 2001 (Fig. 17b), which is the same as the sense of late Quaternary strain across the region. Following the Arequipa earthquake, the frequency and moment release from normal and strike-slip earthquakes in the plateau increased (Fig. 17d). The increase in seismicity does not appear to result from changes in the gCMT catalogue's sensitivity to moderate-magnitude earthquakes, as $70 \%$ of the events in the time-span 1986-2019 are larger than the magnitude of completeness of the pre-2001 gCMT catalogue $\left(\sim M_{w} 5.3\right.$, see Ekström et al. [2012]) . Although we cannot rule out that the post-2001 change in seismicity is unrelated to the Arequipa earthquake (there are too few eyents to define/a background seismicity rate [e.g. Marsan and Nalbant, 2005]), similar changes in the frequency and moment release from overriding plate seismicity have been observed following many megathrust earthquakes [Gomberg and Sherrod, 2014], suggesting a causal relationship.

Later in the postseismic period, between 2008 and 2013, the GPS velocities at all stations had returned to moving landward relative to South America, with shortening concentrated between the coastal stations, and no resolvable strain across the plateau (e.g. compare the motions at stations CONA, AREQ and LAMP on Fig. 17c). This period of near-neutral strain rates saw the two largest recorded normal-faulting earthquakes in the plateau in 2013 and 2016 (Fig. 17d).

The GPS and earthquake observations indicate that the horizontal, elastic compression of the Andes due to the strain accumulation leading up to the 2001 Arequipa earthquake may have been large enough to temporarily suppress slip on some of the normal and strike-slip faults between Cusco and Lagunillas (as suggested in Cascadia by Wang [2000] and in the Makran by Penney et al. [2017]). Coand post-seismic slip on the megathrust relaxed the elastic compression and unclamped the faults in the plateau, causing a pulse of normal- and strike-slip-faulting earthquakes lasting up until present (2019). This pulse of seismicity has accommodated a uni-axial, NNE-SSW extension with a strain rate of $1.7 \times 10^{-9} 1 / \mathrm{yr}$ averaged across the plateau (Fig. $17 \mathrm{~d}$; inset).

Although the 2001-2019 seismicity represents a marked increase in the seismic deformation within the Altiplano compared to the period 1986-2001, the earthquake moment release is still a factor 3-12 too small to account for the late Quaternary slip rates on the Cusco-Lagunillas Faults. Presumably this deformation deficit will be made up by future normal-faulting earthquakes not captured by the moment-tensor summation, and possibly aseismic deformation within the Altiplano, most likely following another megathrust earthquake. Therefore, although the pattern and long-term rate of extension in the Altiplano is set by differences in gravitational potential energy between the plateau interior and its forelands [Dalmayrac and Molnar, 1981; Wimpenny et al., 2018], the timing of slip on the normal faults may be modulated by small perturbations to the force balance caused by the seismic cycle of the megathrusts along the margins of the Andes. A possible test of this hypothesis would be to compare paleoseismological estimates of the timing of earthquakes on the normal faults with the historical record of megathrust earthquakes in south Peru [Silgado, 1978]. 


\section{Conclusions}

We find that a system of 10-20 km-long, right-stepping normal faults between Cusco and Lagunillas in the South Peruvian Altiplano are accommodating $\sim 1-4 \mathrm{~mm} / \mathrm{yr}$ of extension. The azimuth of the extension rotates clockwise from NNE-SSW near Cusco to NE-SW near Parina, which mirrors the rotation of thrust earthquake slip vectors in the sub-Andean foreland. Slip on these normal faults began in the last 1-6 Myrs and has reactivated a number of Miocene-age reverse faults. Evidence for normal faulting dies away towards the south-east, near the border between the Peruvian and Bolivian Altiplano, where most of the faults reverse the local slope direction and are not associated with any large-amplitude topography. The onset of extension in the last $\sim 5$ Myrs followed an episode of shortening that ended in the late Miocene, suggesting that the forces acting on the Andes have changed. To account for the extension rates across the Cusco-Lagunillas Faults, the average shear stresses transmitted across the sub-Andean detachment may have decreased by $\lesssim 4 \mathrm{MPa}$, that is $\lesssim 20$ $25 \%$ of their absolute value. This result highlights the delicate balance of forces that controls the active faulting on the margins of mountain ranges and the faulting within their interiors.

\section{Acknowledgements}

This work forms part of the NERC- and ESRC-funded project Earthquakes without Frontiers and was partly supported by the NERC large grant Looking into Continents from Space. SW was partly supported by the British Geological Survey, a Santander Mobility Grant awarded through the University of Cambridge and the Denman Baynes Senior Studentship at Clare College, University of Cambridge. AOK was partly supported by Arup. SW thanks James Jackson, Thomasina Ball and Nicola D'Agostino for reading earlier versions of the manuscript. The authors thank the Editor, Margarita Segou, Micheal Sebrier, Onno Oncken and an anonymous reviewer for constructive comments on this manuscript.

All geological map data are freely available from INGEMMET's web server GEOCATMIN (http: //geocatmin.ingemmet.gob.pe/geocatmin/). Digital Globe satellite imagery was collected from Google Earth. Pleiades data was obtained from Airbus. 


\section{References}

Armijo, R., Meyer, B., King, G. C., Rigo, A., and Papanastassiou, D. (1996). Quaternary evolution of the Corinth Rift and its implications for the Late Cenozoic evolution of the Aegean. Geophysical Journal International, 126(1):11-53.

Audin, L., David, C., Hall, S., Farber, D., and Herail, G. (2006). Geomorphic Evidences of Recent Tectonic Activity in the Forearc, Southern Peru. Revisita de la Asociacion Geologica Argentina, $61(4): 545-554$.

Bellier, O. (1989). Tectonique en extension et changement d'états de contraintes cénozoüque en domaine intra-continental : exemples des bassins intra-cordillérains des Hautes Andes (Nord Pérou) et du graben de la Wei He (Chine du Nord). PhD thesis, University de Paris-Sud, Orsay.

Benavente, C., Delgado, F., Taipe, E., Audin, L., and Pari, W. (2013). Neotectonica y Peligro Sismico en el Region Cusco. Technical report, Instituto Geologico Minera y Metalurgico.

Bendick, R., Mckenzie, D., and Etienne, J. (2008). Topography associated with crustal flow in continental collisions, with application to Tibet. Geophysical Journal International, 175(1):375-385.

Bevis, M., Kendrick, E., Smalley, R., Brooks, B., Allmendinger, R., and Isacks, B. (2001). On the strength of interplate coupling and the rate of back arc convergence in the central Andes: An analysis of the interseismic velocity field. Geochemistry, Geophysics, Geosystems, 2(11).

Bird, P. and Carafa, M. M. (2016). Improving deformation models by discounting transient signals in geodetic data: 1. Concept and synthetic examples. Journal of Geophysical Research: Solid Earth, 121(7):5538-5556.

Brune, J. N. (1968). Seismic moment, seismicity, and rate of slip along major fault zones. Journal of Geophysical Research, 73(2):777-784.

Cabrera, J. and Sebrier, M. (1998). Surface Rupture Associated with a $5.3 \mathrm{mb}$ Earthquake: The 5 April 1986 Cuzco Earthquake and Kinematics of the Chincheros-Qoricocha Faults of the High Andes, Peru. Bulletin of the Seismological Society of America, 88(1):242-255.

Cabrera, J., Sébrier, M., and Mercier, J. L. (1991). Plio-Quaternary geodynamic evolution of a segment of the Peruvian Andean Cordillera located above the change in the subduction geometry: the Cuzco region. Tectonophysics, 190(2-4):331-362.

Carlotto, V. (2013). Paleogeographic and tectonic controls on the evolution of Cenozoic basins in the Altiplano and Western Cordillera of southern Peru. Tectonophysics, 589:195-219.

Carlotto, V. and Cardenas, J. (2009). Mapa Geologico del Cuadrangulo de Ocuviri Escala 1:50,000 Hoja 31-u Cuadrante IV.

Carlotto, V., Mejia, R. R., and Mena, M. O. (2009). Mapa Geologico del Cuadrangulo del Cusco Escala 1:50,000 Hoja 28-s Cuadrante II.

Carlotto, V., Mejia, R. R., and Mena, M. O. (2010). Mapa Geologico del Cuadrangulo del Cusco Escala 1:50,000 Hoja 28-vs Cuadrante IV. 
Carlotto, V. and Roque, J. C. (2009). Mapa Geologico del Cuadrangulo de Sicuani Escala 1:50,000 Hoja 29-t Cuadrante II.

Chlieh, M., Perfettini, H., Tavera, H., Avouac, J.-P., Remy, D., Nocquet, J.-M., Rolandone, F., Bondoux, F., Gabalda, G., and Bonvalot, S. (2011). Interseismic coupling and seismic potential along the Central Andes subduction zone. Journal of Geophysical Research: Solid Earth, 116(B12):B12405.

Clark, P. U., Dyke, A. S., Shakun, J. D., Carlson, A. E., Clark, J., Wohlfarth, B., Mitrovica, J. X., Hostetler, S. W., and McCabe, A. M. (2009). The Last Glacial Maximum. Science, 325(5941):710714.

Copley, A. (2017). The strength of earthquake-generating faults. Journal of the Geological Society, 174.

Cornet, F. H. and Röckel, T. (2012). Vertical stress profiles and the significance of "stress decoupling". Tectonophysics, 581:193-205.

D'Agostino, N., Jackson, J. A., Dramis, F., and Funiciello, R. (2001). Interactions between mantle upwelling, drainage evolution and active normal faulting: An example from the Central Appennines (Italy). Geophysical Journal International, 147(2):475-497.

Dalmayrac, B. and Molnar, P. (1981). Parallel thrust and normal faulting in Peru and constraints on the state of stress. Earth and Planetary Science Letters, 55(3):473-481.

D'Arcy, M., Schildgen, T. F., Strecker, M. R., Wittmann, H., Duesing, W., Mey, J., Tofelde, S., Weissmann, P., and Alonso, R. N. (2019). Timing of past glaciation at the Sierra de Aconquija, northwestern Argentina, and throughout the Central Andes. Quaternary Science Reviews, 204:3757.

Devlin, S., Isacks, B. L., Pritchard, M. E., Barnhart, W. D., and Lohman, R. B. (2012). Depths and focal mechanisms of crustal earthquakes in the central Andes determined from teleseismic waveform analysis and InSAR. Tectonics, 31(2):1-33.

Di Naccio, D., Kastelic, V., Carafa, M. M., Esposito, C., Milillo, P., and Di Lorenzo, C. (2019). Gravity Versus Tectonics: The Case of 2016 Amatrice and Norcia (Central Italy) Earthquakes Surface Coseismic Fractures. Journal of Geophysical Research: Earth Surface, 124(4):994-1017.

Dziewonski, A. M., Chou, T.-A., and Woodhouse, J. H. (1981). Determination of earthquake source parameters from waveform data for studies of global and regional seismicity. Journal of Geophysical Research: Solid Earth, 86(B4):2825-2852.

Ekström, G., Nettles, M., and Dziewoński, A. (2012). The global CMT project 2004âĂŞ2010: Centroid-moment tensors for 13,017 earthquakes. Physics of the Earth and Planetary Interiors, 200:1-9.

Emmerson, B. (2007). The relationship between intraplate earthquakes and temperature. PhD thesis, University of Cambridge.

England, P. and Houseman, G. (1989). Extension during continental convergence, with application to the Tibetan Plateau. Journal of Geophysical Research, 94(B12):17561. 
England, P. and McKenzie, D. (1982). A thin viscous sheet model for continental deformation. Geophysical Journal International, 70(2):295-321.

England, P. and Molnar, P. (1997a). Active Deformation of Asia: From Kinematics to Dynamics. Science, 278(5338):647-650.

England, P. and Molnar, P. (1997b). The field of crustal velocity in Asia calculated from Quaternary rates of slip on faults. Geophysical Journal International, 130(3):551-582.

England, P. C., Houseman, G. A., Osmaston, M. F., and Ghosh, S. (1988). The Mechanics of the Tibetan Plateau [and Discussion]. Philosophical Transactions of the Royal Society A: Mathematical, Physical and Engineering Sciences, 326(1589):301-320.

Ericksen, G. E., Fernandez Concha, J., and Silgado, E. (1954). The Cusco, Peru, Earthquake of May 21 1950. Bulletin of the Seismological Society of America, 44(2A):97-112.

Fan, G., Wallace, T. C., Beck, S. L., and Chase, C. G. (1996). Gravity anomaly and flexural model: constraints on the structure beneath the Peruvian Andes. Tectonophysics, 255(1-2):99-109.

Finocchio, D., Barba, S., and Basili, R. (2016). Slip rate depth distribution for active faults in Central Italy using numerical models. Tectonophysics, 687:232-244.

Flesch, L. M., Haines, A. J., and Holt, W. E. (2001). Dynamics of the India-Eurasia collision zone. Journal of Geophysical Research: Solid Earth, 106(B8):16435-16460.

Fraser, C. S. and Hanley, H. B. (2005). Bias-compensated RPCs for Sensor Orientation of Highresolution Satellite Imagery. Photogrammetric Engineering \& Remote Sensing, 71(8):909-915.

Garzione, C. N., McQuarrie, N., Peréz, N. D., Ehlers, T. A., Beck, S. L., Kar, N., Eichelberger, N., Chapman, A. D., Ward, K. M., Ducea, M. N., Lease, R. O., Poulsen, C. J., Wagner, L. S., Saylor, J. E., Zandt, G., and Horton, B. K. (2017). Tectonic Evolution of the Central Andean Plateau and Implications for the Growth of Plateaus. Annual Review of Earth and Planetary Sciences, 45:529-559.

Goldsworthy, M. and Jackson, J. A. (2000). Active normal fault evolution in Greece revealed by geomorphology and drainage patterns. Journal of the Geological Society, 157(5):967-981.

Gomberg, J. and Sherrod, B. (2014). Crustal earthquake triggering by modern great earthquakes on subduction zone thrusts. Journal of Geophysical Research: Solid Earth, 119(2):1235-1250.

Goodman, A. Y., Rodbell, D. T., Seltzer, G. O., and Mark, B. G. (2001). Subdivision of glacial deposits in southeastern Peru based on pedogenic development and radiometric ages. Quaternary Research, 56(1):31-50.

Grützner, C., Schneiderwind, S., Papanikolaou, I., Deligiannakis, G., Pallikarakis, A., and Reicherter, K. (2016). New constraints on extensional tectonics and seismic hazard in northern Attica, Greece: The case of the Milesi Fault. Geophysical Journal International, 204(1):180-199.

Gubbels, T. L., Isacks, B. L., and Farrar, E. (1993). High-level surfaces, plateau uplift, and foreland development, Bolivian central Andes. Geology, 21(8):695. 
Haines, A. J. and Holt, W. E. (1993). A procedure for obtaining the complete horizontal motions within zones of distributed deformation from the inversion of strain rate data. Journal of Geophysical Research: Solid Earth, 98(B7):12057-12082.

Hogg, A. G., Hua, Q., Blackwell, P. G., Niu, M., Buck, C. E., Guilderson, T. P., Heaton, T. J., Palmer, J. G., Reimer, P. J., Reimer, R. W., Turney, C. S. M., and Zimmerman, S. R. H. (2013). SHCal13 Southern Hemisphere Calibration, 0âĂŞ50,000 Years cal BP. Radiocarbon, 55(04):1889-1903.

Horton, B. K., Perez, N. D., Fitch, J. D., and Saylor, J. E. (2015). Punctuated shortening and subsidence in the Altiplano Plateau of southern Peru: Implications for early Andean mountain building. Lithosphere, $7(2): 117-137$.

Husson, L. and Ricard, Y. (2004). Stress balance above subduction: Application to the Andes. Earth and Planetary Science Letters, 222(3-4):1037-1050.

Jackson, J. A. (2002). Strength of the continental lithosphere: Time to abandon the jelly sandwich? GSA Today, 12(9):4.

Jackson, J. A. and McKenzie, D. (1999). A hectare of fresh striations on the Arkitsa Fault, central Greece. Journal of Structural Geology, 21(1):1-6.

Jackson, J. A. and White, N. J. (1989). Normal faulting in the upper continental crust: observations from regions of active extension. Journal of Structural Geology, 11(1-2):15-36.

Jay, J. A., Delgado, F. J., Torres, J. L., Pritchard, M. E., Macedo, O., and Aguilar, V. (2015). Deformation and seismicity near Sabancaya volcano, southern Peru, from 2002 to 2015. Geophysical Research Letters, 42(8):2780-2788.

Jomelli, V., Favier, V., Vuille, M., Braucher, R., Martin, L., Blard, P. H., Colose, C., Brunstein, D., He, F., Khodri, M., Bourlès, D. L., Leanni, L., Rinterknecht, V., Grancher, D., Francou, B., Ceballos, J. L., Fonseca, H., Liu, Z., and Otto-Bliesner, B. L. (2014). A major advance of tropical Andean glaciers during the Antarctic cold reversal. Nature, 513(7517):224-228.

Kar, N., Garzione, C. N., Jaramillo, C., Shanahan, T., Carlotto, V., Pullen, A., Moreno, F., Anderson, V., Moreno, E., and Eiler, J. (2016). Rapid regional surface uplift of the northern Altiplano plateau revealed by multiproxy paleoclimate reconstruction. Earth and Planetary Science Letters, 447:33-47.

Kendrick, E., Bevis, M., Smalley, R., and Brooks, B. (2001). An integrated crustal velocity field for the central Andes. Geochemistry, Geophysics, Geosystems, 2.

Kley, J. (1996). Transition from basement-involved to thin-skinned thrusting in the Cordillera Oriental of southern Bolivia. Tectonics, 15(4):763-775.

Lamb, S. (2006). Shear stresses on megathrusts: Implications for mountain building behind subduction zones. Journal of Geophysical Research: Solid Earth, 111(B7):B07401.

Lamb, S. and Hoke, L. (1997). Origin of the high plateau in the Central Andes, Bolivia, South America. Journal of Geophysical Research: Solid Earth, 16(4):623-649.

Lamb, S. H. (2000). Active deformation in the Bolivian Andes, South America. Journal of Geophysical Research: Solid Earth, 105(B11):25627-25653. 
Ma, Y. and Clayton, R. W. (2014). The crust and uppermost mantle structure of Southern Peru from ambient noise and earthquake surface wave analysis. Earth and Planetary Science Letters, 395:61-70.

Mackenzie, D. and Elliott, A. (2017). Untangling tectonic slip from the potentially misleading effects of landform geometry. Geosphere, 13(4):1310-1328.

Marsan, D. and Nalbant, S. S. (2005). Methods for measuring seismicity rate changes: A review and a study of how the Mw 7.3 landers earthquake affected the aftershock sequence of the Mw 6.1 Joshua Tree earthquake.

Marsh, E. J., Bruno, M. C., Fritz, S. C., Baker, P., Capriles, J. M., and Hastorf, C. A. (2018). IntCal, SHCal, or a Mixed Curve? Choosing a 14C Calibration Curve for Archaeological and Paleoenvironmental Records from Tropical South America. Radiocarbon, 60(03):925-940.

Mercer, J. H. and Palacios, M. O. (1977). Radiocarbon dating of the last glaciation in Peru. Geology, $5(10): 600$.

Mercier, J. L., Sebrier, M., Lavenu, A., Cabrera, J., Bellier, O., Dumont, J.-F., and Machrare, J. (1992). Changes in the tectonic regime above a subduction zone of Andean Type: The Andes of Peru and Bolivia during the Pliocene-Pleistocene. Journal of Geophysical Research, 97(B8):11945.

Miller, D. J. and Dunne, T. (1996). Topographic perturbations of regional stresses and consequent bedrock fracturing. Journal of Geophysical Research: Solid Earth, 101(B11):25523-25536.

Molnar, P. (1988). Continental tectonics in the aftermath of plate tectonics. Nature, 335(6186):131137.

Molnar, P. and Lyon-Caen, H. (1988). Some simple physical aspects of the support, structure, and evolution of mountain belts. In Geological Society of America Special Papers, volume 218, pages 179-208. Geological Society of America.

Mouslopoulou, V., Walsh, J. J., and Nicol, A. (2009). Fault displacement rates on a range of timescales. Earth and Planetary Science Letters, 278(3-4):186-197.

Oncken, O., Boutelier, D., Dresen, G., and Schemmann, K. (2012). Strain accumulation controls failure of a plate boundary zone: Linking deformation of the Central Andes and lithosphere mechanics. Geochemistry, Geophysics, Geosystems, 13(12).

Penney, C., Tavakoli, F., Saadat, A., Nankali, H. R., Sedighi, M., Khorrami, F., Sobouti, F., Rafi, Z., Copley, A., Jackson, J., and Priestley, K. (2017). Megathrust and accretionary wedge properties and behaviour in the Makran subduction zone. Geophysical Journal International, 209(3):1800-1830.

Perez, N., Horton, B., McQuarrie, N., Stubner, K., and Ehlers, T. (2016a). Andean shortening, inversion and exhumation associated with thin- and thick-skinned deformation in southern Peru. Geological Magazine, 153(5-6):1013-1041.

Perez, N. D. and Horton, B. K. (2014). Oligocene-miocene deformational and depositional history of the andean hinterland basin in the northern altiplano Plateau, Southern Peru. Tectonics, 33(9):18191847. 
Perez, N. D., Horton, B. K., and Carlotto, V. (2016b). Structural inheritance and selective reactivation in the central Andes: Cenozoic deformation guided by pre-Andean structures in southern Peru. Tectonophysics, 671:264-280.

Placzek, C. J., Quade, J., and Patchett, P. J. (2013). A 130ka reconstruction of rainfall on the Bolivian Altiplano. Earth and Planetary Science Letters, 363:97-108.

Pritchard, M. E., Norabuena, E. O., Ji, C., Boroschek, R., Comte, D., Simons, M., Dixon, T. H., and Rosen, P. A. (2007). Geodetic, teleseismic, and strong motion constraints on slip from recent southern Peru subduction zone earthquakes. Journal of Geophysical Research, 112(B3):B03307.

Ranalli, G. (1995). Rheology of the Earth. Chapman \& Hall.

Roberts, G. P. (1996). Variation in fault-slip directions along active and segmented normal fault systems. Journal of Structural Geology, 18(6):835-845.

Rodbell, D. T., Smith, J. A., and Mark, B. G. (2009). Glaciation in the Andes during the Lateglacial and Holocene. Quaternary Science Reviews, 28(21-22):2165-2212.

Rossell, L. (2018). Estudio Morfotectonico y Paleosismico de las Fallas Tambomachay y Qoricocha, Implicancia en el Peligro Seismico de la Region Cusco. Masters thesis, Universidad Nacional de San Antonio Abab del Cusco.

Saillard, M., Audin, L., Rousset, B., Avouac, J. P., Chlieh, M., Hall, S. R., Husson, L., and Farber, D. L. (2017). From the seismic cycle to long-term deformation: linking seismic coupling and Quaternary coastal geomorphology along the Andean megathrust. Tectonics, 36(2):241-256.

Schoenbohm, L. M. and Strecker, M. R. (2009). Normal faulting along the southern margin of the Puna Plateau, northwest Argentina. Tectonics, 28(5):TC5008.

Sébrier, M., Mercier, J. L., Mégard, F., Laubacher, G., and Carey-Gailhardis, E. (1985). Quaternary normal and reverse faulting and the state of stress in the central Andes of south Peru. Tectonics, $4(7): 739-780$.

Seltzer, G. O. (1990). Recent glacial history and paleoclimate of the Peruvian-Bolivian Andes. Quaternary Science Reviews, 9(2-3):137-152.

Silgado, E. (1978). Historia de los Sismos Mas Notables Ocurridos en el Peru (1513-1974). Technical report, Instituto de Geologia y Mineria, Lima.

Smith, J. A., Seltzer, G. O., Rodbell, D. T., and Klein, A. G. (2005). Regional synthesis of last glacial maximum snowlines in the tropical Andes, South America. Quaternary International, 138-139:145167.

Smith, W. H. F. and Wessel, P. (1990). Gridding with continuous curvature splines in tension. Geophysics, 55(3):193-305.

Suarez, G., Molnar, P., and Burchfiel, B. C. (1983). Seismicity, fault plane solutions, depth of faulting, and active tectonics of the Andes of Peru, Ecuador, and southern Colombia. Journal of Geophysical Research, 88(B12):10403-10428. 
Talebian, M., Copley, A. C., Fattahi, M., Ghorashi, M., Jackson, J. A., Nazari, H., Sloan, R. A., and Walker, R. T. (2016). Active faulting within a megacity: The geometry and slip rate of the Pardisan thrust in central Tehran, Iran. Geophysical Journal International, 207(3):1688-1699.

Thompson, S. C., Weldon, R. J., Rubin, C. M., Abdrakhmatov, K., Molnar, P., and Berger, G. W. (2002). Late Quaternary slip rates across the central Tien Shan, Kyrgyzstan, central Asia. Journal of Geophysical Research: Solid Earth, 107(B9):7-32.

Turcotte, D. L. and Schubert, G. (2002). Geodynamics. Cambridge University Press.

Villegas-Lanza, J. C., Chlieh, M., Cavalié, O., Tavera, H., Baby, P., Chire-Chira, J., and Nocquet, J. M. (2016). Active tectonics of Peru: Heterogeneous interseismic coupling along the Nazca megathrust, rigid motion of the Peruvian Sliver, and Subandean shortening accommodation. Journal of Geophysical Research: Solid Earth, 121(10):7371-7394.

Walker, R. and Jackson, J. (2004). Active tectonics and late Cenozoic strain distribution in central and eastern Iran. Tectonics, 23(5):TC5010.

Wang, K. (2000). Stress-strain 'paradox', plate coupling, and forearc seismicity at the Cascadia and Nankai subduction zones. Tectonophysics, 319(4):321-338.

Wang, K. and Dixon, T. (2004). "Coupling" Semantics and Science in Earthquake Research. Eos, Transactions American Geophysical Union, 85(18):180-181.

Wang, K. and He, J. (1999). Mechanics of low-stress forearcs: Nankai and Cascadia. Journal of Geophysical Research: Solid Earth, 104(B7):15191-15205.

Ward, D. J., Cesta, J. M., Galewsky, J., and Sagredo, E. (2015). Late pleistocene glaciations of the arid subtropical Andes and new results from the Chajnantor Plateau, northern Chile. Quaternary Science Reviews, 128:98-116.

Wells, D. L. and Coppersmith, K. J. (1994). New empirical relationships among magnitude, rupture length, rupture width, rupture area, and surface displacement. Bulletin of the Seismological Society of America, 84(4):974-1002.

Westoby, M., Brasington, J., Glasser, N., Hambrey, M., and Reynolds, J. (2012). âĂ ̈̈Structure-fromMotion' photogrammetry: A low-cost, effective tool for geoscience applications. Geomorphology, 179:300-314.

Wimpenny, S., Copley, A., Benavente Escobar, C. L., and Aguirre, E. (2018). Extension and Dynamics of the Andes inferred from the 2016 Parina (Huarichancara) Earthquake. Journal of Geophysical Research: Solid Earth, 123(9):8198-8228.

Zhou, Y., Parsons, B., Elliott, J. R., Barisin, I., and Walker, R. T. (2015). Assessing the ability of Pleiades stereo imagery to determine height changes in earthquakes: A case study for the El Mayor-Cucapah epicentral area. Journal of Geophysical Research: Solid Earth, 120(12):8793-8808. 


\section{Tables}

Table 1: Results of bulk radiocarbon dating of samples collected in south Peru performed by Beta Analytic (FL, USA). Calibration is performed using the Southern Hemisphere-specific calibration SHCAL13 [Hogg et al., 2013]. The influence of Northern Hemisphere-derived carbon on the calibration [see Marsh et al., 2018] is probably negligible relative to the uncertainties associated with younger/older carbon inheritance common to bulk sampling. Calibrated ages are given in years before 1950 with formal uncertainties $2 \sigma$ about the mean, though typical uncertainties are $\sim 1 \mathrm{kyr}$.

\begin{tabular}{ccccc}
\hline Sample & Material & $\delta^{13} C$ (\% per mill.) & Age (yr BC) & Calibrated Age (cal. yr BP) \\
\hline QR-1 & Organic sediment & -25.1 & $6756-6566$ & $8705-8515$ \\
SR-1 & Organic sediment & -24.5 & $5511-5364$ & $7460-7313$ \\
SR-2 & Organic sediment & -25.4 & $5470-5304$ & $7419-7253$ \\
\hline
\end{tabular}


Table 2: Measurements from active faults in south Peru. $v_{\text {slip }}$ is the fault slip rate, $v_{\text {hor }}$ is the horizontal extension rate (heave rate) and $\phi_{s v}$ is the slip vector azimuth. LGM refers to landforms that have been assumed to be Last Glacial Maximum in age.

\begin{tabular}{ccccccc}
\hline Fault & Landform & Dating & Age (ka) & $v_{\text {slip }}(\mathrm{mm} / \mathrm{yr})$ & $v_{\text {hor }}(\mathrm{mm} / \mathrm{yr})$ & $\phi_{s v}(\mathrm{deg})$ \\
\hline Qoricocha & drift & radiocarbon & $8-45$ & $0.2-1.4$ & $0.2-1.1$ & 201 \\
Tambomachay & lateral moraine & radiocarbon & $8-45$ & $0.1-0.4$ & $0.1-0.3$ & $198-205$ \\
Pachatusan & lateral moraine & LGM & $10-45$ & $0.5-3.1$ & $0.4-2.0$ & $\sim 210$ \\
Sangarara & alluvial fan & radiocarbon & $10-20$ & $3.6-7.9$ & $2.0-4.5$ & 190 \\
Vilacota & lateral moraine & LGM & $10-45$ & $0.1-1.6$ & $0.1-0.8$ & 192 \\
Parina & lateral moraine & LGM & $10-45$ & $0.1-1.4$ & $0.1-1.1$ & $235-245$ \\
\hline
\end{tabular}




\section{Figures}

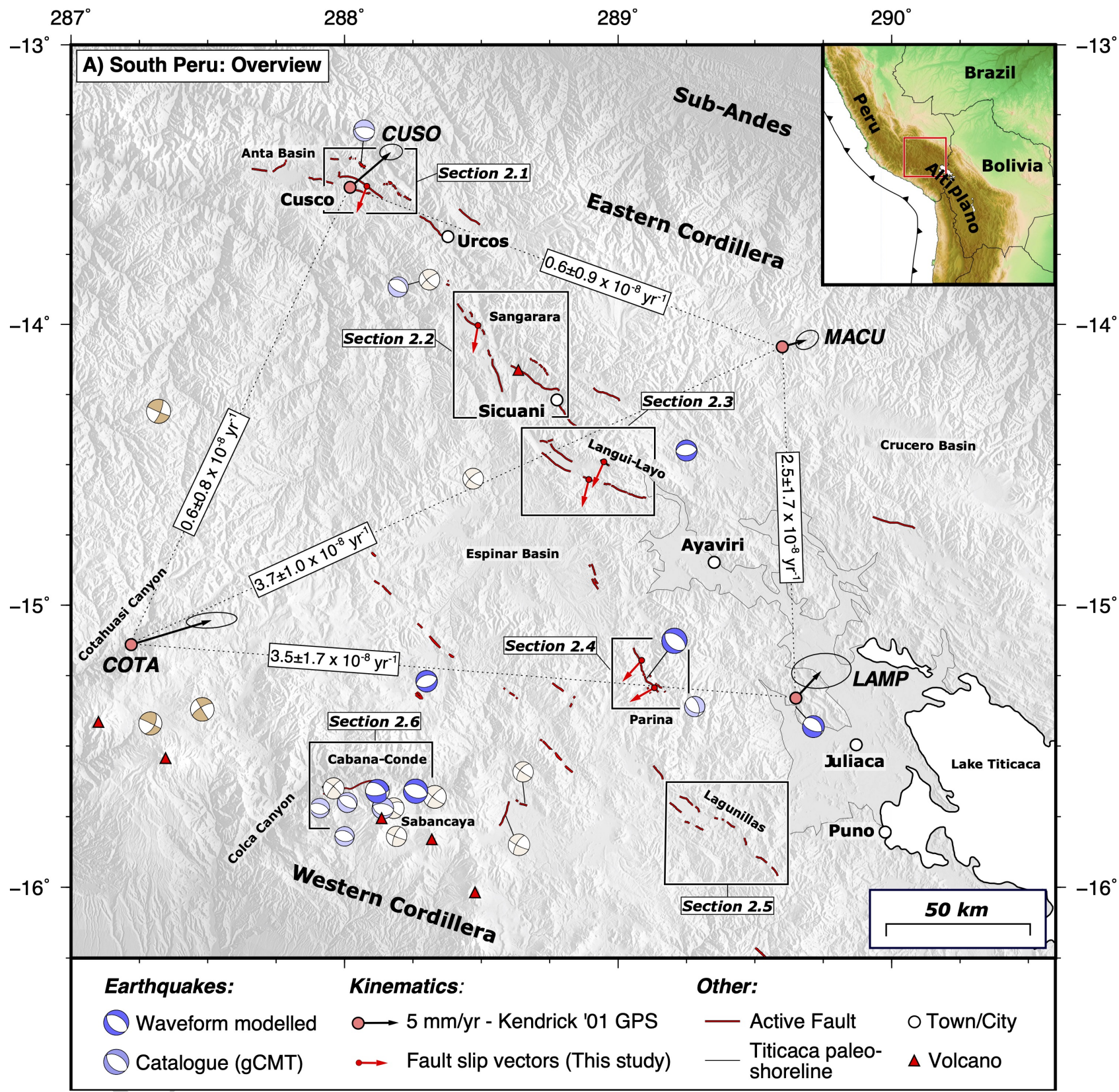

Figure 1: Mapped active faults in south Peru. Faults traces were mapped using the field and satellite remote-sensing observations from this study, as well as the mapping of Benavente et al. [2013] and Mercier et al. [1992]. Boxes refer to the regions discussed in Section 2. Waveform-modelled earthquakes with centroid depths $<50 \mathrm{~km}$ (i.e. those in the overriding lithosphere and not in the slab) are taken from Suarez et al. [1983], Devlin et al. [2012], Wimpenny et al. [2018] and references therein. Catalogue earthquakes have $M_{w}>5$ and were retrieved from the global CMT in March 2019 [Dziewonski et al., 1981; Ekström et al., 2012]. GPS velocities were collected between 1993 and 2000 by Kendrick et al. [2001] and are shown relative to stable South America with $1 \sigma(68 \%)$ uncertainty ellipses. Strain rates between the GPS stations are shown in the grey boxes with $1 \sigma$ uncertainties, using the convention that positive values represent shortening. 

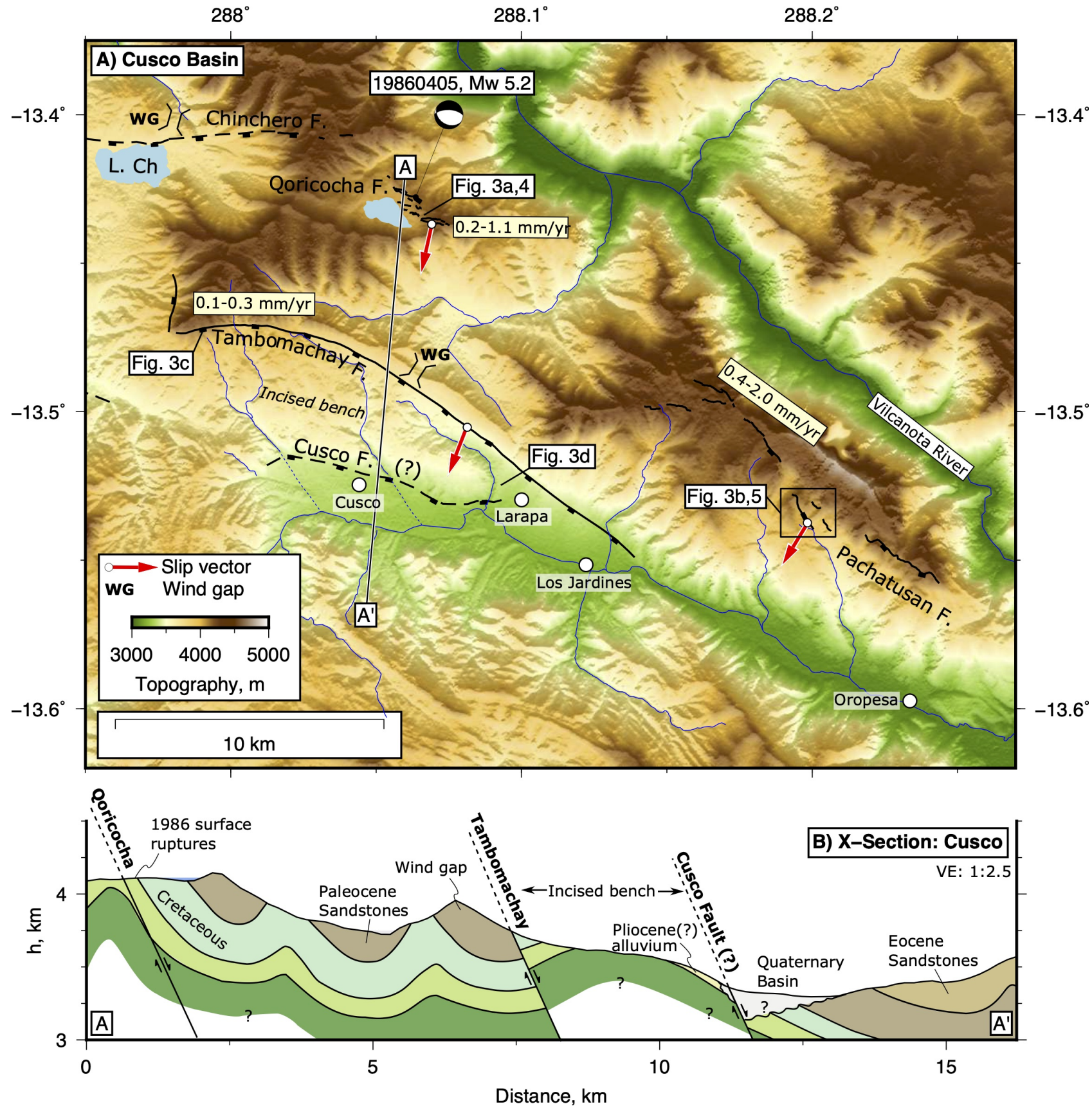

Figure 2: Morphology and active faults of the Cusco Basin. (a) SRTM $30 \mathrm{~m}$ DEM of the Cusco region with active faults and slip vectors marked. The fault map is updated from those of Cabrera et al. [1991] and Mercier et al. [1992]. Solid lines are observed faults, dashed lines are inferred faults and blue lines mark rivers. Estimates of the fault extension rates are shown in light yellow boxes (see text for discussion). The mechanism for the 5th April 1986 earthquake is taken from the gCMT catalogue. (b) Cross section perpendicular to the active normal faults in the west of the Cusco Basin. The sub-surface geology is taken from the INGEMMET 1:50,000 Cusco sheet 28-s-IV [Carlotto et al., 2010]. The exact throw across the Tambomachay Fault is not well known. 

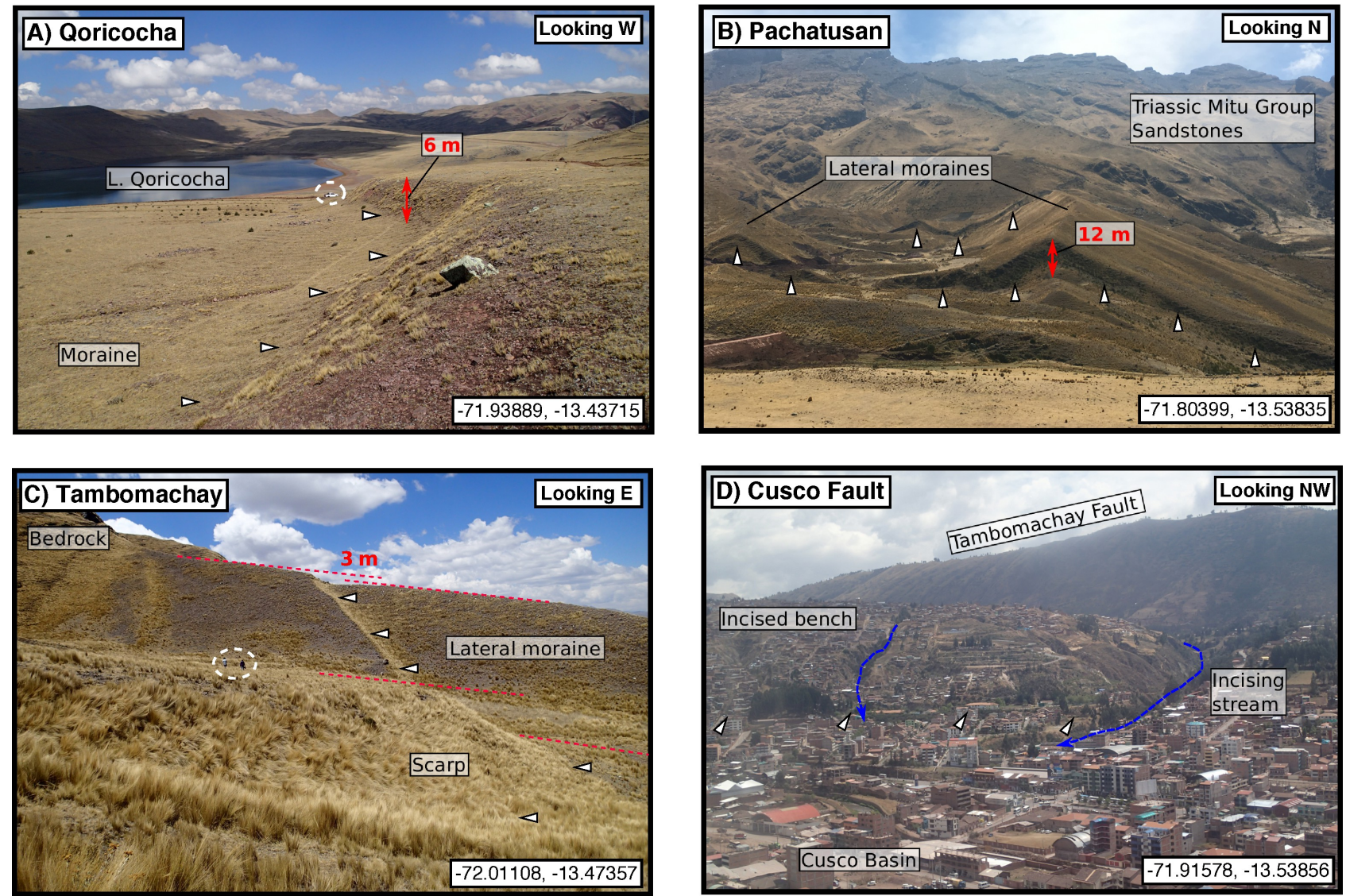

Figure 3: Field photographs of fault scarps around Cusco. White triangles indicate the fault scarps and red dashed lines mark the fault offsets. (a) South-facing scarp of the Qoricocha Fault, with Lake Qoricocha visible in the background. The vehicle highlighted in the background for scale (white dashed circle) is located next to the road cut shown in Fig. 4. (b) Sub-parallel normal fault scarps cutting lateral moraine crests on the Pachatusan Fault. Scarp offsets are measured from the DEM shown in Fig. 5. (c) South-facing normal-fault scarp of the Tambomachay Fault cutting a lateral moraine crest. People in the foreground for scale (white circle). (d) Uplifted and incised hangingwall of the Tambomachay Fault, with the ridge line of the Tambomachay Fault footwall visible in the background. The Cusco Fault runs along the sharp step in topography visible in the foreground, and is responsible for the incised drainage. 

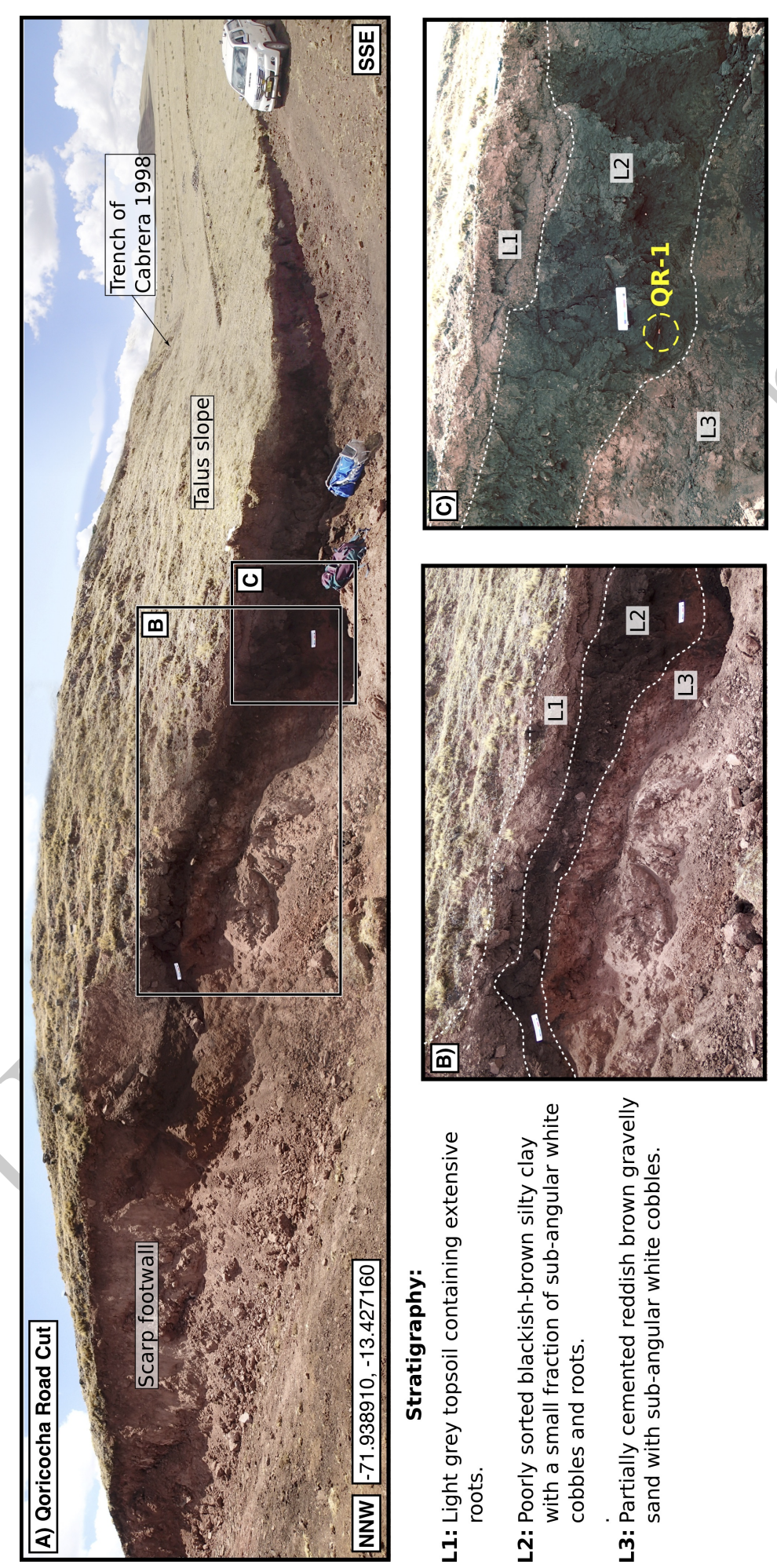

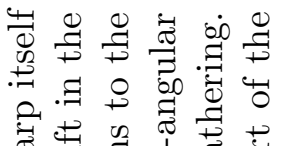

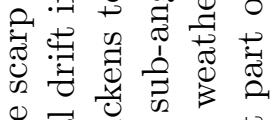

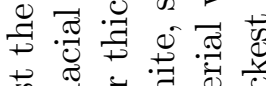
苟营

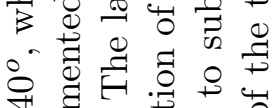
स द्व पे 0.

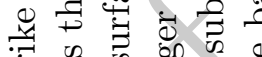
की $\approx \leftrightarrow$ क्षे जै

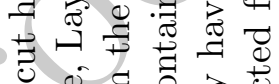

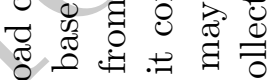

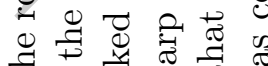

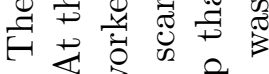
$\dot{1} \dot{0}$

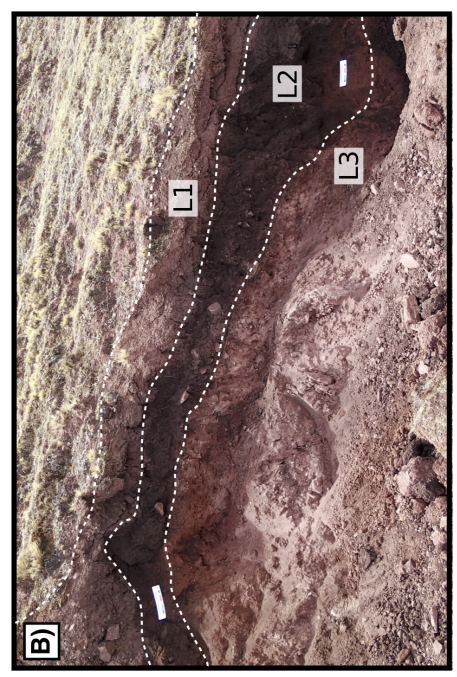

đृ

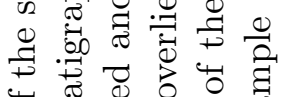
范茟 दी की क्ष.

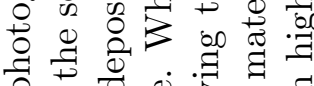

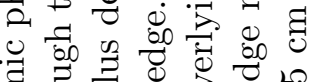

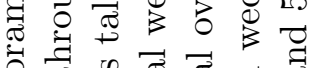
요

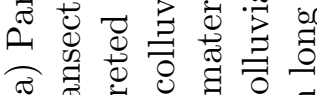
๘

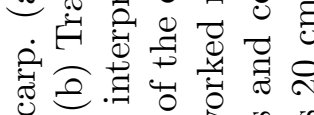

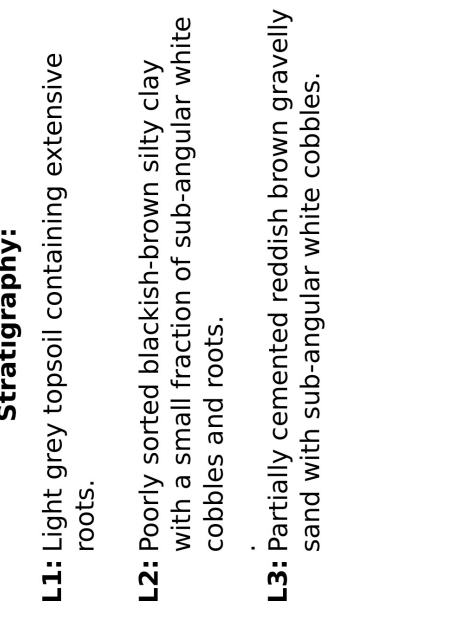
क 巧 卷

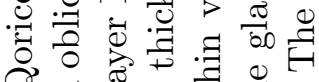
O $\exists \equiv . \pi$ os .

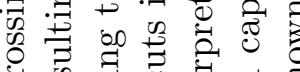

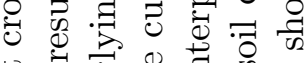
욜 옥

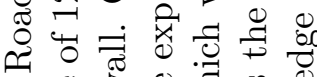

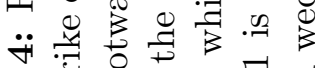

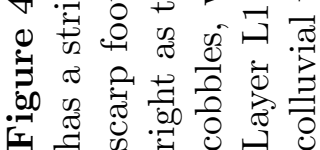



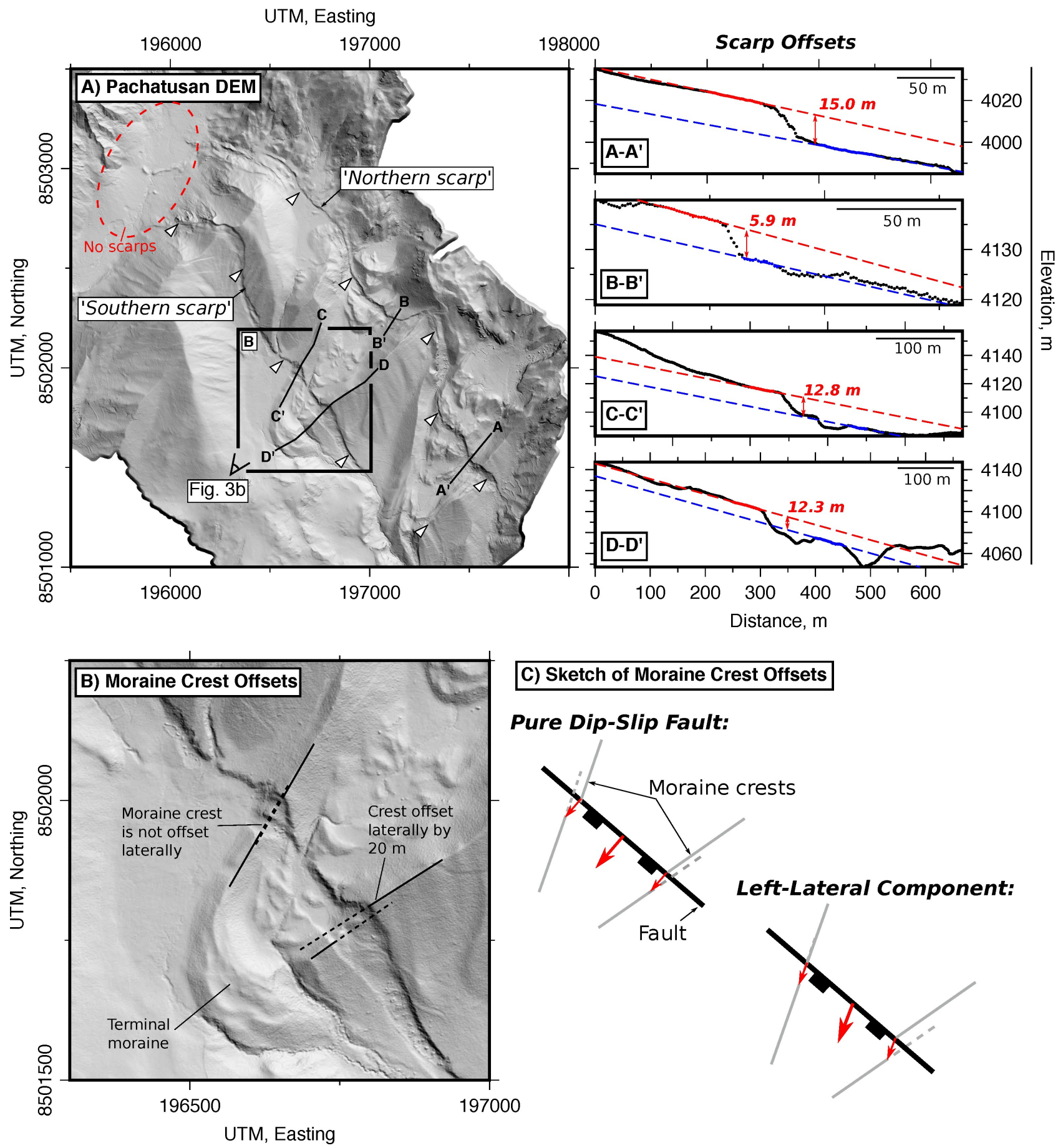

Figure 5: High-resolution DEM of the Pachatusan Fault. (a) Hillshade of the DEM (illuminated from the NE) highlighting the two sets of sub-parallel scarps cutting lateral moraine deposits. Topographic profiles across the scarps are shown in the adjacent boxes. On the profiles, black dots are the measured elevations (relative elevations are accurate but absolute elevations are not), dashed lines are linear fits to the coloured points above (red) and below (blue) the scarp. The vertical scarp offset was measured as the difference between these two lines at the foot of the scarp. (b) Zoom in on the region in (a) with laterally-offset moraines. The moraine crests have been projected by black dashed lines. (c) Sketches of the moraine crest offsets expected for different fault slip vectors. 

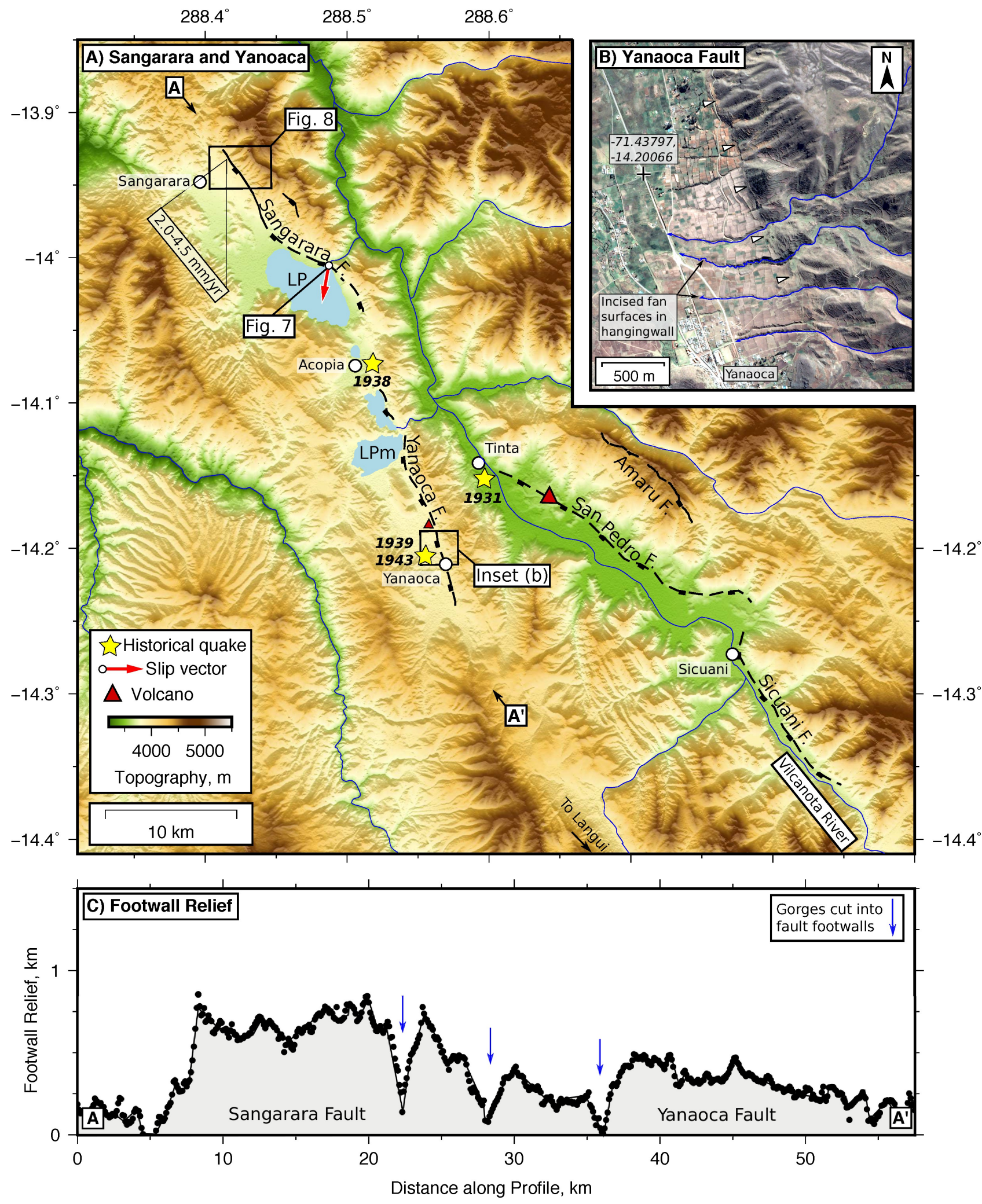

Figure 6: Overview of the active faulting between Sangarara and Yanoaca. (a) SRTM $30 \mathrm{~m}$ DEM overlain with active faults. The legend is the same as in Fig. 2. The two lakes are: LP = Lake Pomacanchi and LPm = Lake Pampamarca. (b) Digital Globe imagery from Google Earth of incision across the bedrock-alluvium contact along the Yanaoca Fault. Incision is also present in the hangingwall fan surfaces at Sangarara (see Fig. 8). (c) Footwall relief along the Sangarara-Yanaoca valley. 

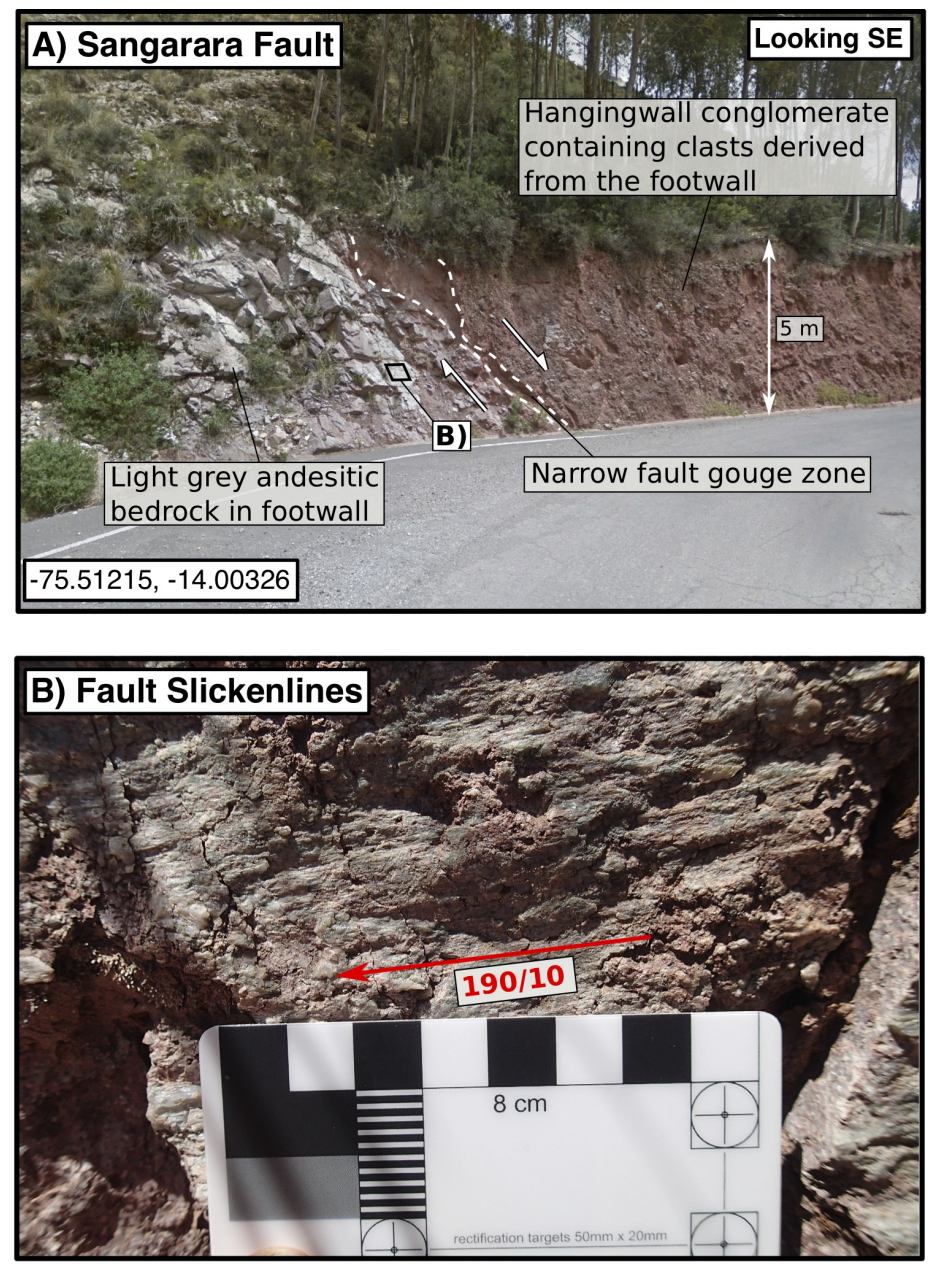

Figure 7: Field photographs of the Sangarara Fault at the head of the gorge draining Lake Pomacanchi. (a) The contact between andesitic footwall bedrock and the hangingwall conglomerates exposed in a road cut. (b) Slickenlines in green precipitate on the fault surface. The slickenlines have a small plunge at this tocality (i.e. mostly strike-slip motion), as this particular exposed section of the Sangarara Fault is within an oblique step over (see Fig. 6a). 

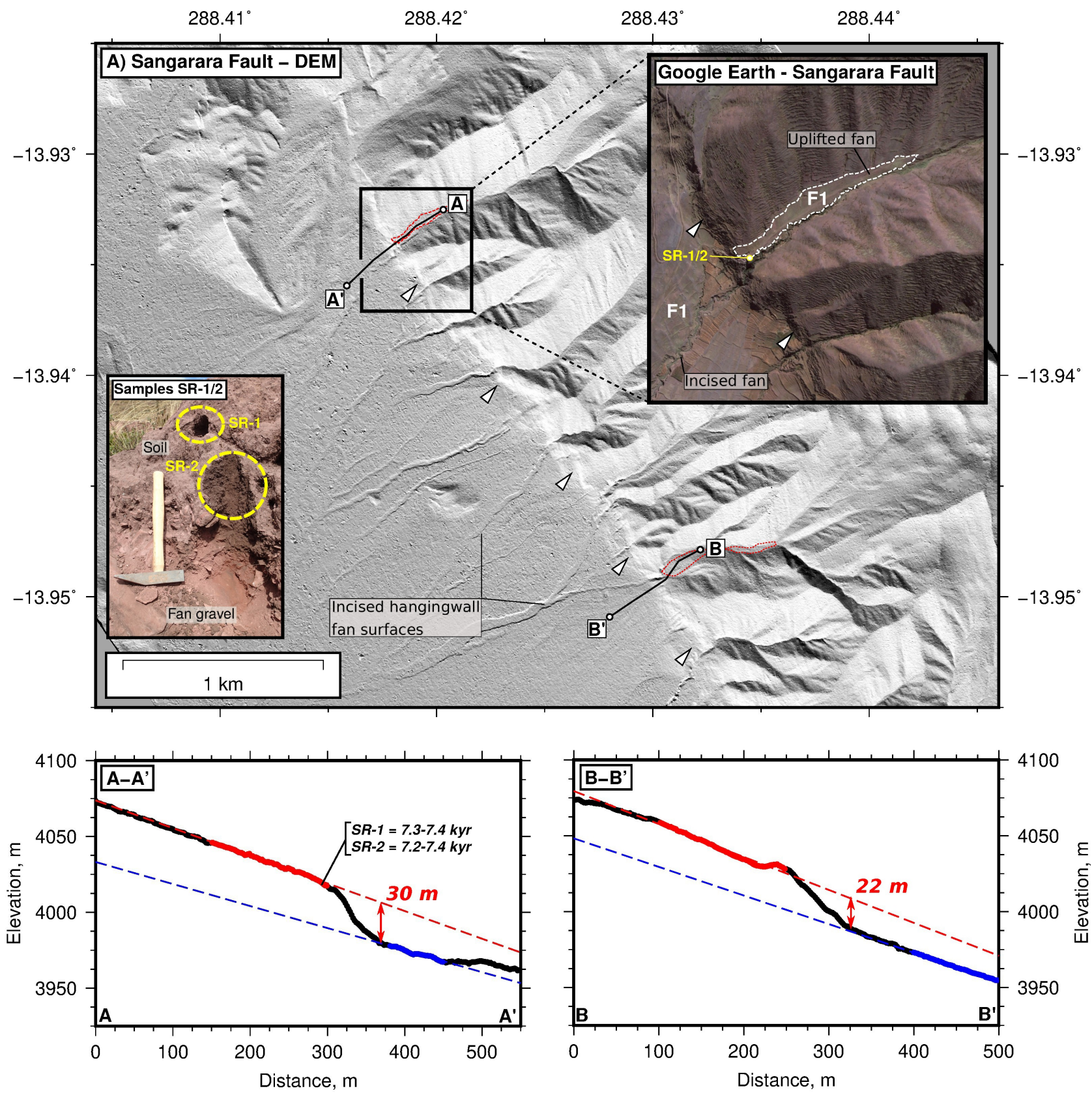

Figure 8: Pleiades satellite DEM, sample locations and profiles used to estimate the slip rate on the Sangarara Fault. (a) Hillshade of the Pleiades DEM gridded at $1 \mathrm{~m}$ resolution (see text for the method used to construct the DEM). Inset is a Digital Globe satellite image from Google Earth of the offset fan surface (F1; highlighted in white), with the location of the samples SR-1 and SR-2 also highlighted. Photographs of the soil samples collected from the top of the fan are also shown inset. Topographic profiles between points A-A' and B-B' are shown below. These profiles are along curved traces as they track down-dip on the fan surfaces. 

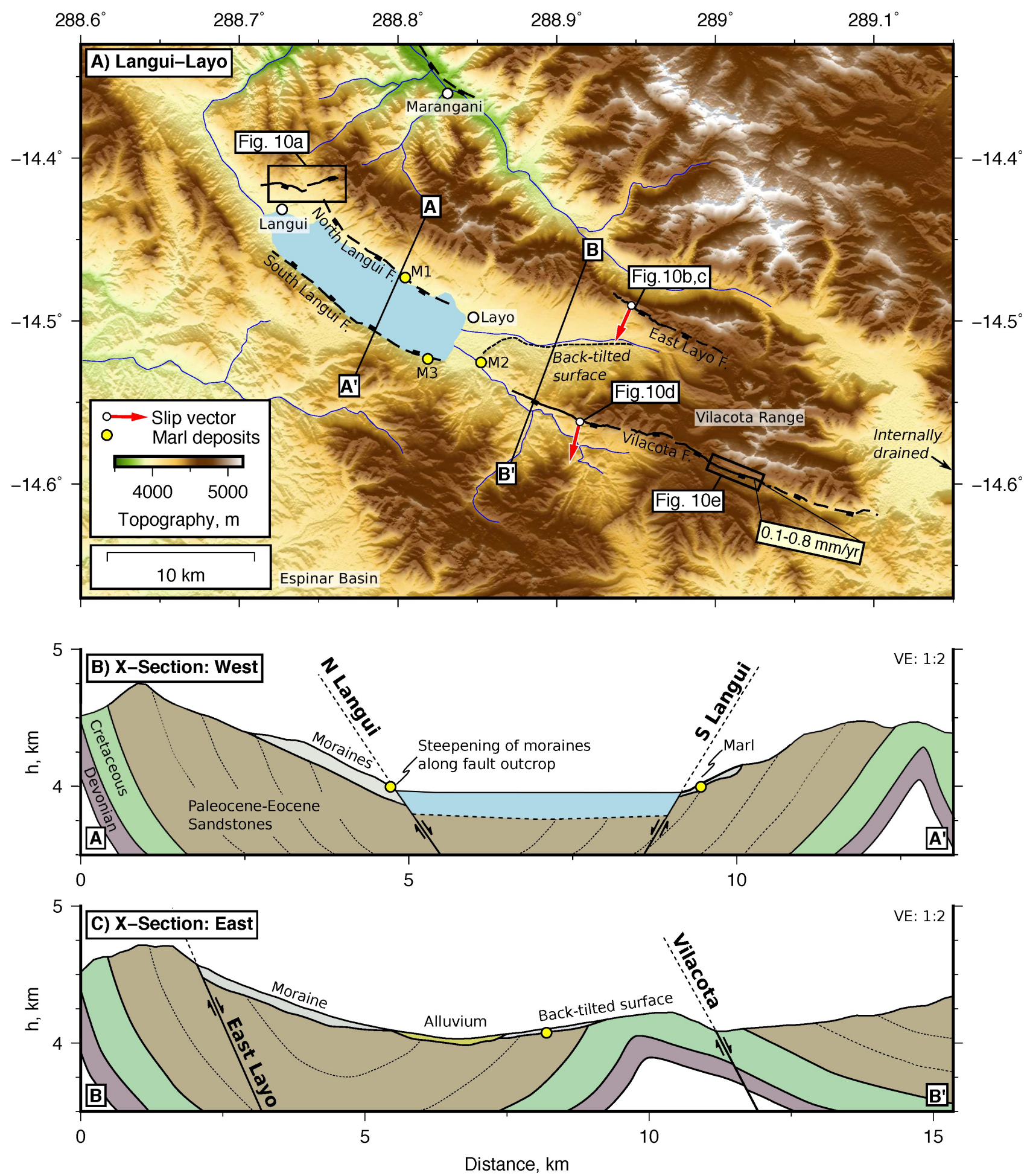

Figure 9: Overview of the active faulting around the Langui-Layo Basin. (a) SRTM $30 \mathrm{~m}$ DEM and active fault map. The locations of three exposures of marl layers around the edge of the lake are highlighted with yellow dots. Photographs and satellite imagery are shown in Fig. 10 and a detailed view of the marl deposit at locality M2 is shown in Fig. S3. A high-resolution Pleaides DEM of the Vilacota Fault is shown in Fig. S4. (b,c) Geological and topographic cross-sections through the centre and eastern part of the Langui-Layo Basin. The surface geology is taken from the INGEMMET 1:50,000 Sicuani Sheet 29-t-II [Carlotto and Roque, 2009]. 

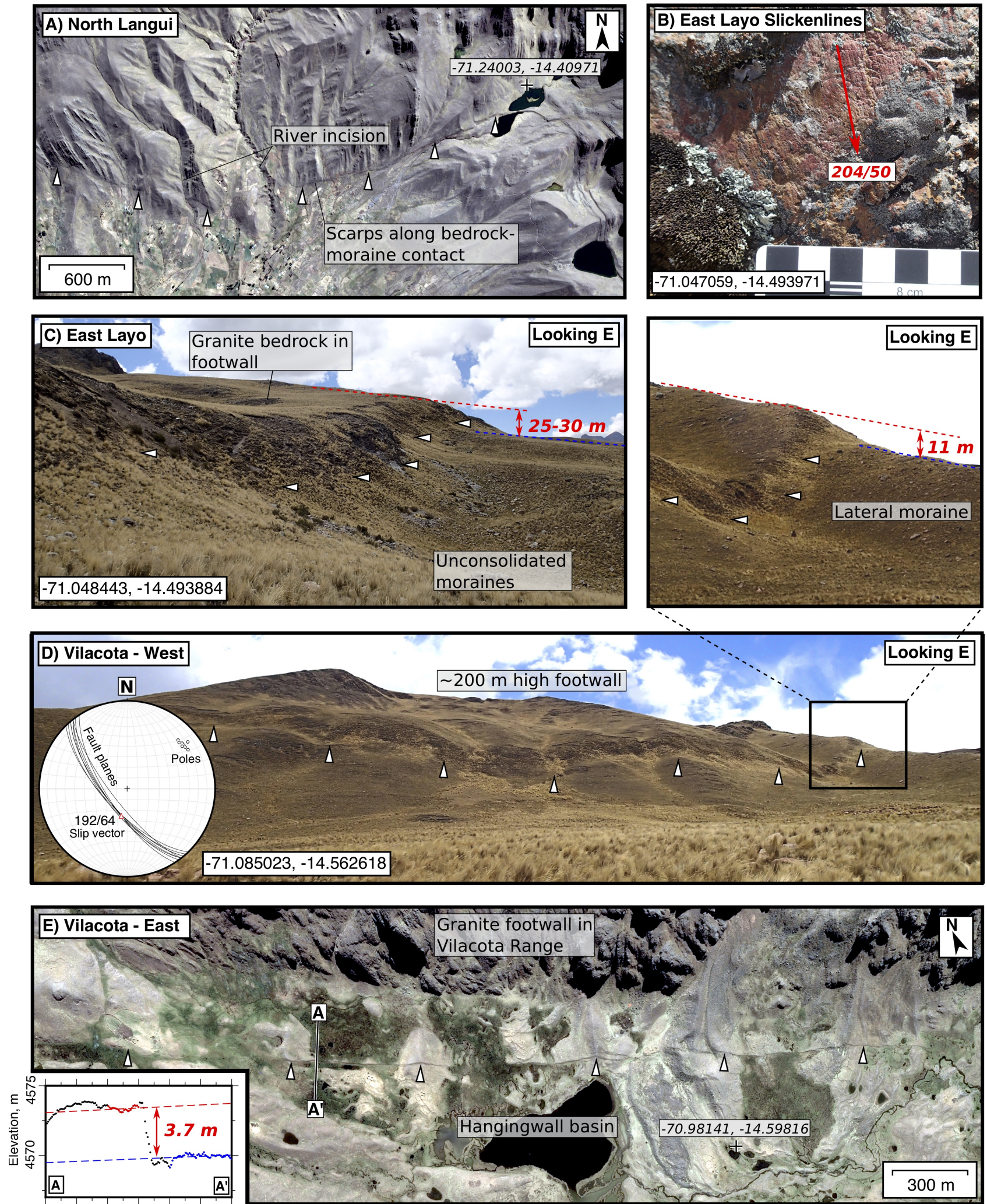

$0 \quad 50 \quad 100150200250300$ Distance, $\mathrm{m}$

Figure 10: Photographs and satellite imagery of faults around Langui-Layo. (a) Digital Globe image from Google Earth of a scarp along the bedrock-alluvium contact north of Langui identified by Sébrier et al. [1985]. (b) Slickenlines on the surface of the East Layo Fault (the scale card has $1 \mathrm{~cm}$ increments). (c) Photograph of the East Layo Fault showing the 25-30 m vertical offset measured from SRTM 30 m DEM. (d) Panoramic photograph of the Vilacota Fault cutting lateral moraine deposits near its western tip (zoom shown inset). Also inset is a collection of fault plane orientation measurements from this section of the fault. The slip vector of the fault plane is marked by the small red triangle with orientation 192/64. (e) Digital Globe image from Google Earth of the scarps in the eastern portion of the Vilacota Fault cutting glacial deposits draped off the high Vilacota Range to the north. Inset is an elevation profile taken across the scarp from the Pleiades DEM shown in Fig. S4. 

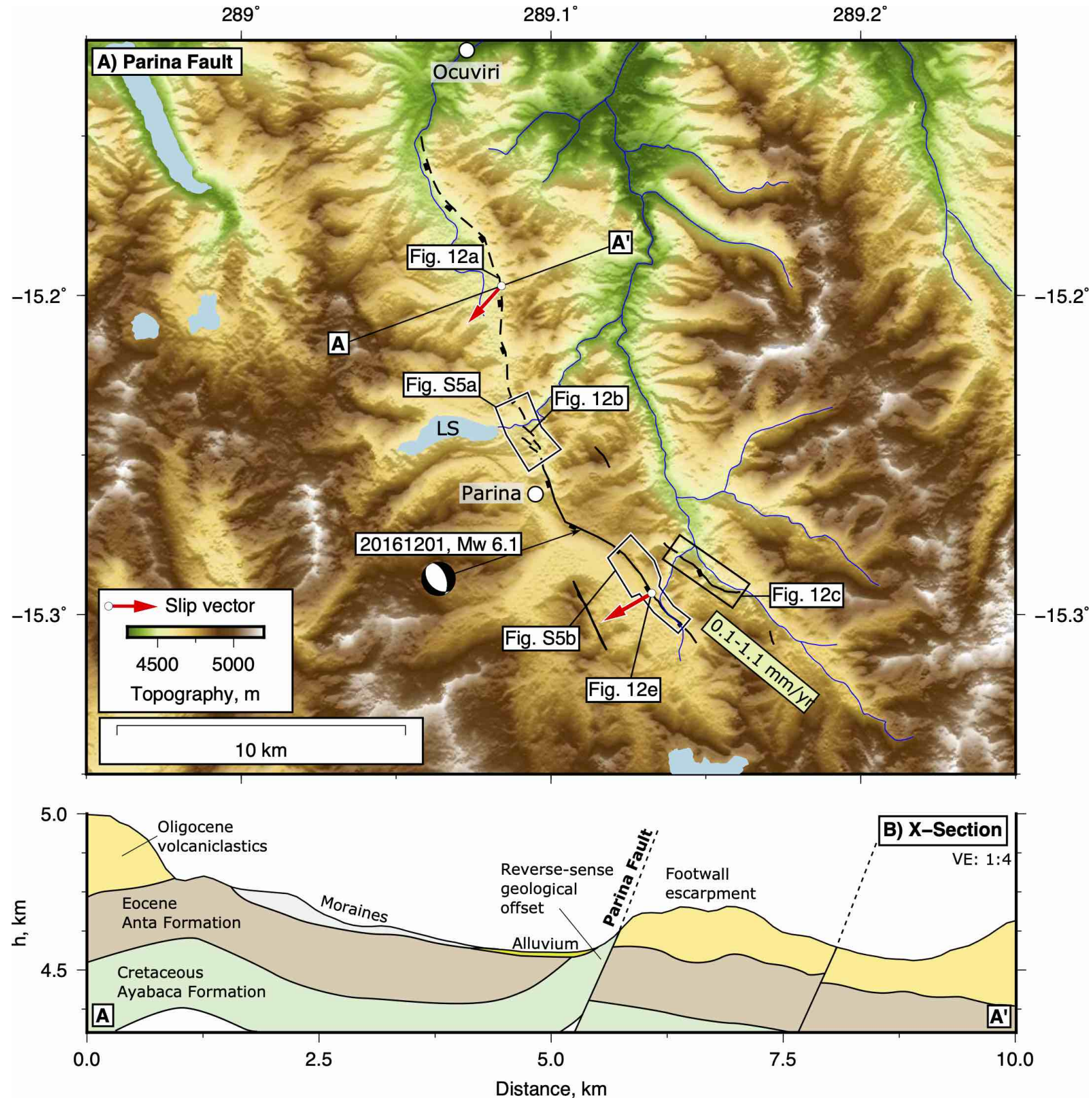

Figure 11: Overview of active faults at Parina. (a) SRTM $30 \mathrm{~m}$ DEM and mapped active faults. LS $=$ Lake Saguanani. Field photographs of the fault scarps are shown in Fig. 12. Drone DEMs over the northern and southern section of the fault that ruptured in the 2016 Parina earthquake are shown in Fig. S5. The 12th December 2016 Parina earthquake moment tensor was determined by modelling teleseismic body-waveforms, InSAR observations and surface ruptures in Wimpenny et al. [2018]. (b) Geological and topographic cross section across the northern section of the Parina Fault, with the geology taken from the INGEMMET 1:50,000 Ocuviri Sheet 31-u-IV [Carlotto and Cardenas, 2009]. 

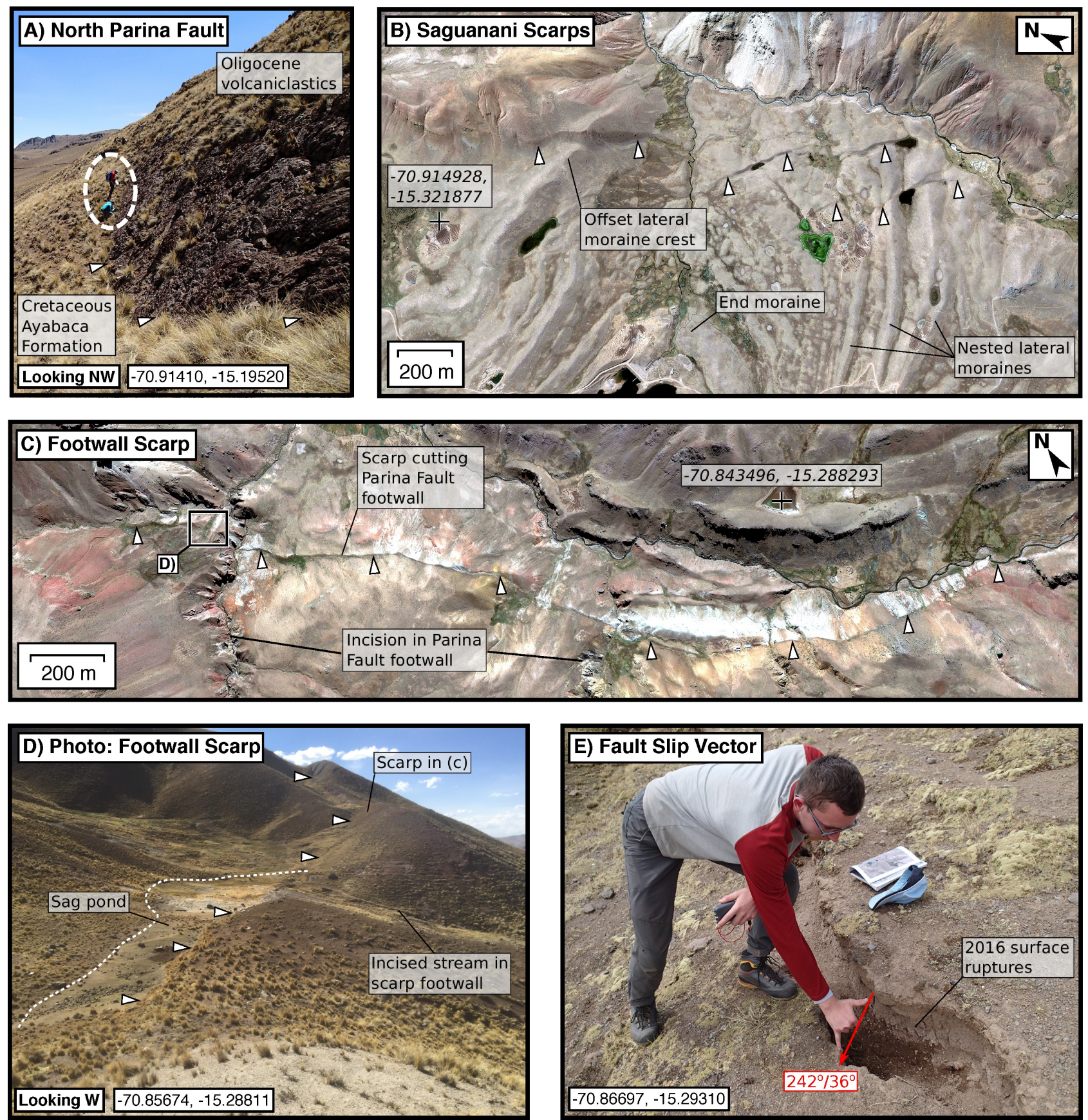

Figure 12: Photographs and satellite imagery of fault scarps at Parina. (a) Exposed bedrock fault plane between Ocuviri and Lake Saguanani at the location of the cross section in Fig. 11b. People are highlighted for scale. (b) Fault scarps cutting lateral moraines near Lake Saguanani that were coincident with surface ruptures from the 2016 Parina earthquake. Topographic profiles across these scarps are shown in Fig. S4. (c) Digital Globe image from Google Earth of a fault scarp cutting the footwall of the Parina Fault. (d) Photograph of a sag pond along the scarp cutting the Parina Fault footwall shown in (c). (e) Photograph of the surface ruptures of the 2016 Parina earthquake and the offset features that can be used to reconstruct the fault slip vector (red arrow). 


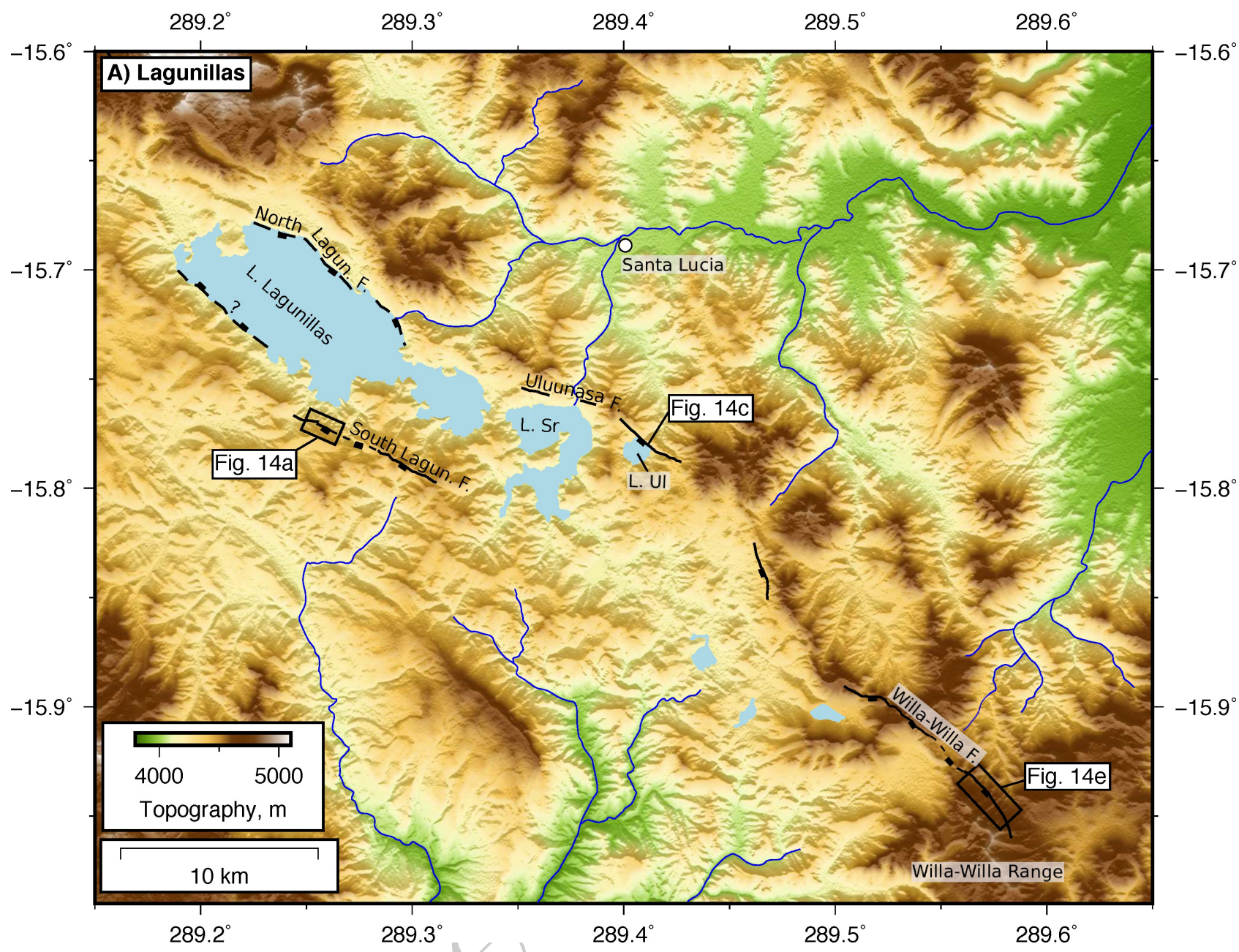

Figure 13: SRTM $30 \mathrm{~m} \mathrm{DEM}$ and active faults near Lake Lagunillas and Santa Lucia. The lakes are: L. SR = Lake Sararacocha and L. Ul = Lake Ululunasa. Photographs and satellite imagery of the faults are shown in Fig. 14. 

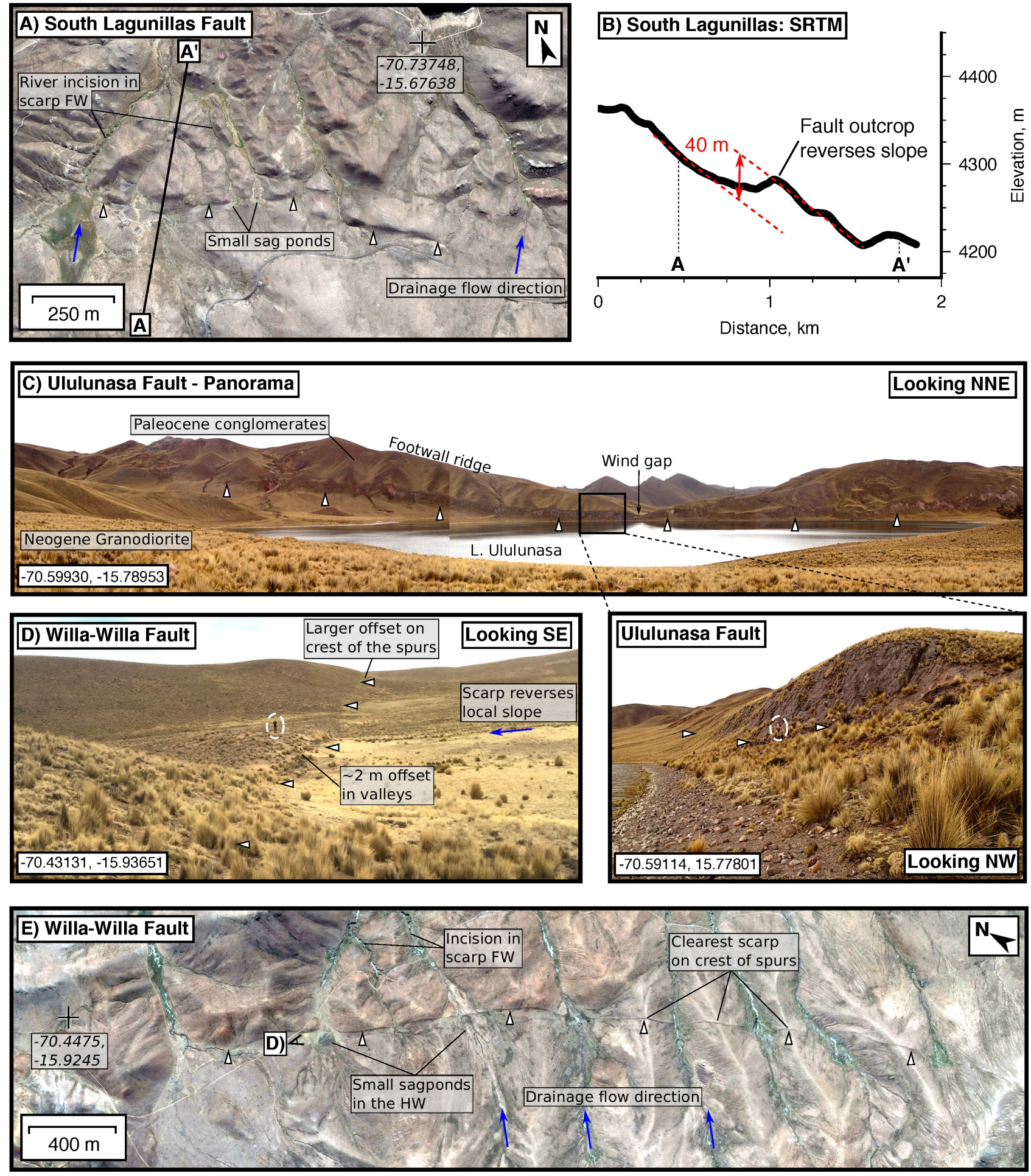

Figure 14: Satellite imagery and photographs of faults near Lake Lagunillas. (a) Digital Globe image from Google Earth of the South Lagunillas Fault (see Fig. 13). (b) Topographic profile extracted from the SRTM $30 \mathrm{~m}$ DEM across the scarp in (a). (c) Panoramic photograph of the Ululunasa Fault. The fault is damming a small lake by uplifting its outlet, forming a wind gap on the northern shore. A photograph of the exposed fault scarp is shown inset. (d) Photograph of the Willa-Willa Fault with people highlighted by a white circle for scale. (e) Digital Globe image from Google Earth of the Willa-Willa Fault cutting across NE-SW trending spurs and reversing the local slope direction. 


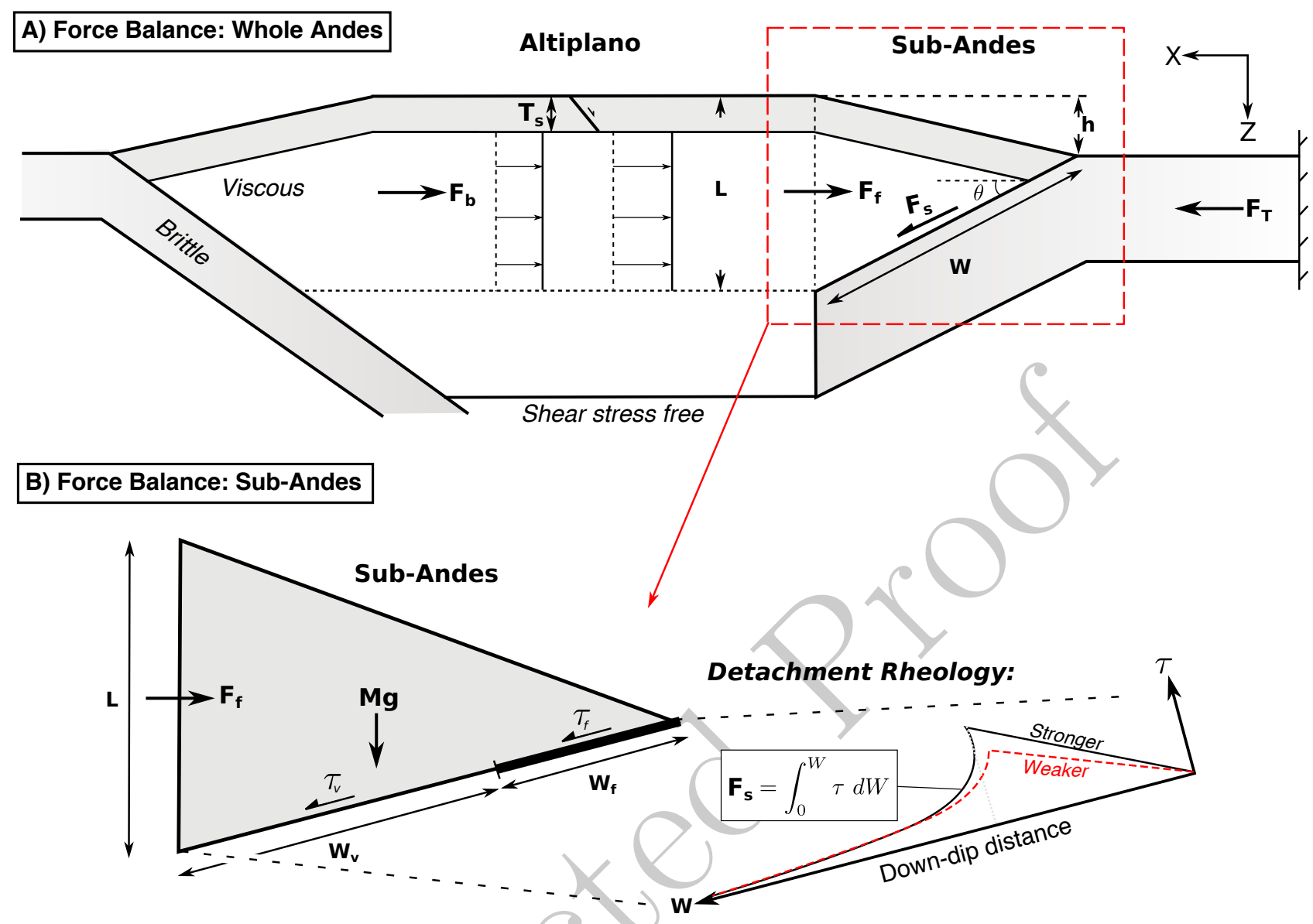

Figure 15: Schematic of the model used to study the force balance in the Andes. (a) A sketch of the force balance across the eastern Andes. $F_{b}$ are the buoyancy forces caused by horizontal differences in the lithostatic stress, $F_{s}$ is the shear force on the sub-Andean detachment and $F_{f}$ is the horizontal force acting on the back of the sub-Andes. (b) Sketch of the force balance in the sub-Andes modified from Lamb [2006]. Frictional and viscous shear stresses on the detachment are denoted $\tau_{f}$ and $\tau_{v}$, respectively, and $M g$ is the weight of the wedge. Inset is a schematic of the shear stress distribution as a function of down-dip width along the detachment for two cases: a frictionally weak and frictionally strong detachment. We explore the influence of changing the frictional shear strength of the detachment $\left(W_{f}, \tau_{f}\right)$ on $F_{s}$ in Fig. 16b. The down-dip width of mechanical coupling $(W)$ on the surface of the underthrusting Brazilian Shield may be unrelated to kinematically-measured coupling [Wang and Dixon, 2004]. 


\section{Shear Stress, MPa}

$\begin{array}{llllll}1 & 5 & 10 & 15 & 20 & 25\end{array}$
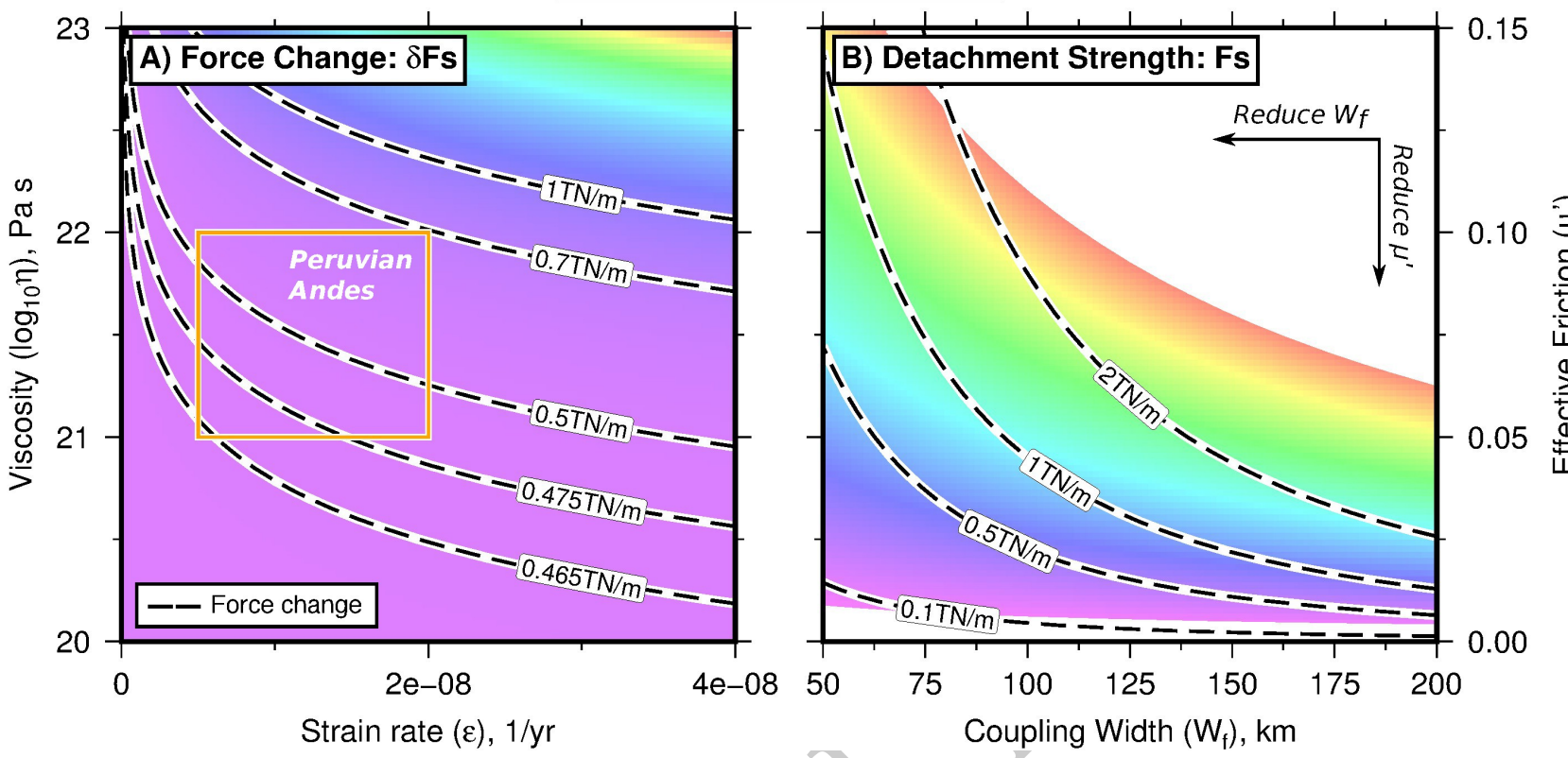

Figure 16: Changes in the force balance needed to account for the slip rates of normal faulting in the Andes. All forces are given in $\mathrm{N}$ per metre along-strike $(\mathrm{N} / \mathrm{m})$, as we only consider forces acting in cross-section. (a) The shear stress change (coloured background) and shear force change (contours) on the sub-Andean detachment required to account for the late Quaternary extension rate in the south Peru (orange box). Calculations were performed with $W=200 \mathrm{~km}, h=4 \mathrm{~km}, \theta=7^{\circ}, \mu^{\prime}=0.2$ and $T_{s}$ $=10 \mathrm{~km}$. (b) Estimates of the average shear stress (coloured background) and shear force (contours) supported by frictional resistance on the sub-Andean detachment for a given frictionally-coupled width and effective coefficient of friction (using Equation 8 of Wang and He [1999]). Calculations in (b) have been performed with the same $W, h$ and $\theta$ as in (a). 

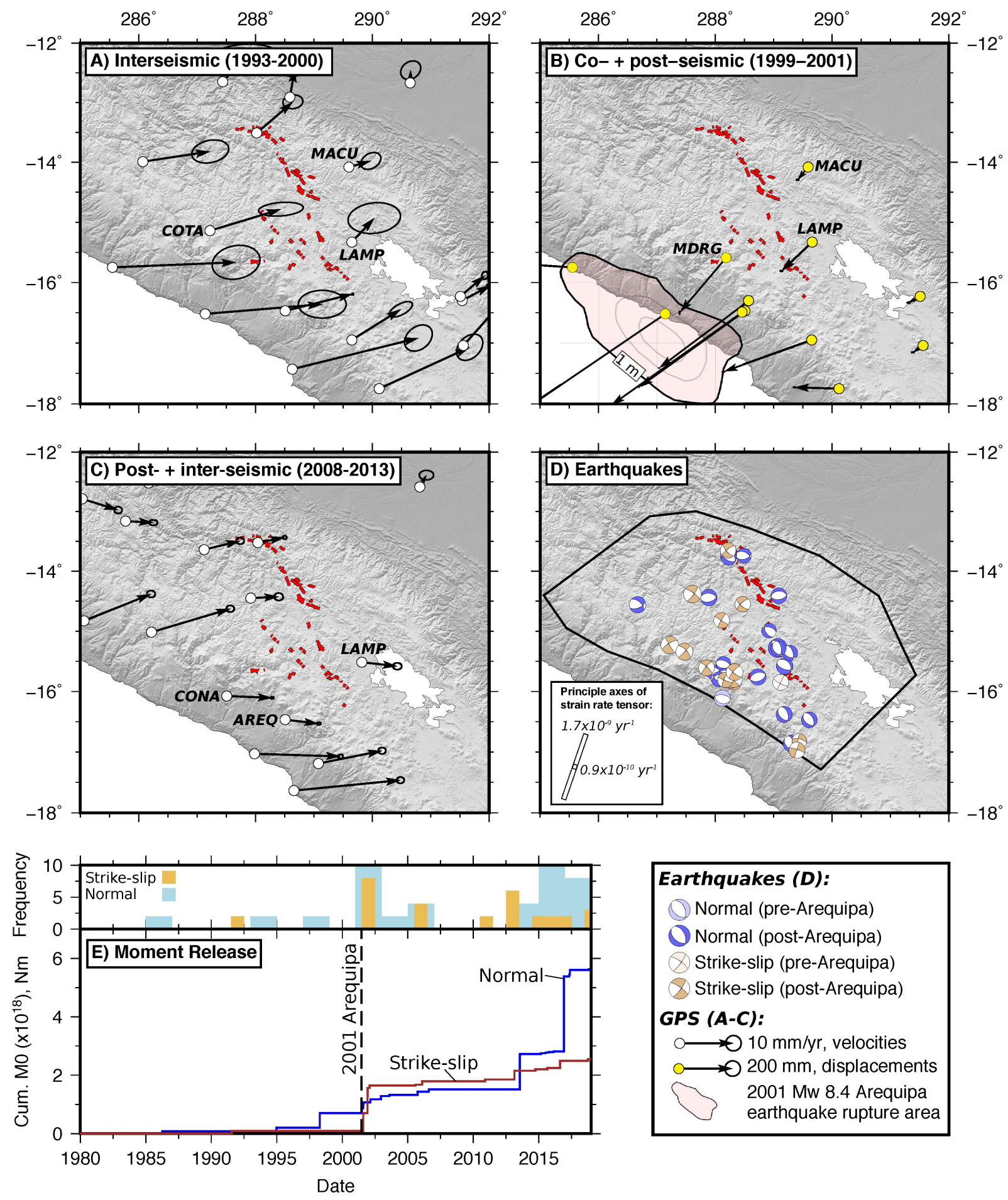

Figure 17: Transient strain in south Peru. (a) Interseismic GPS measurements of the velocity field between 1993 and 2000 from Kendrick et al. [2001]. All GPS measurements are relative to stable South America. Red lines are the mapped normal faults. (b) Co- and early post-seismic displacements from Pritchard et al. [2007] spanning June 1999 to October 2001, capturing the deformation in the 2001 $M_{w} 8.4$ Arequipa earthquake. The $1 \mathrm{~m}$ (black), $3 \mathrm{~m}$ and $5 \mathrm{~m}$ (grey) coseismic slip contours for the Arequipa earthquake are taken from Chlieh et al. [2011] . (c) Late postseismic velocities measured by Villegas-Lanza et al. [2016] between 2008 and 2013. (d) Shallow $(<50 \mathrm{~km})$ earthquakes with $M_{w}>4.5$ beneath the high Andes taken from the global CMT catalogue as of June 2019. Inset are the principle axes of the strain rate tensor derived from a summation of the post-Arequipa earthquake moment tensors (2001-2019). White bars represent extension. The summation is performed over the black box in (d) and by taking a seismogenic thickness of $10 \mathrm{~km}$. (e) Cumulative moment release from earthquakes in the high Andes as a function of time, with all mechanisms shown in (d). 